\title{
Animal models of allergen-specific immunotherapy in food allergy: Overview and opportunities
}

\author{
Larsen, Jeppe Madura; Bøgh, Katrine Lindholm
}

Published in:

Clinical and Experimental Allergy

Link to article, DOI:

$10.1111 /$ cea. 13212

Publication date:

2018

Document Version

Peer reviewed version

Link back to DTU Orbit

Citation (APA):

Larsen, J. M., \& Bøgh, K. L. (2018). Animal models of allergen-specific immunotherapy in food allergy: Overview and opportunities. Clinical and Experimental Allergy, 48(10), 1255-1274. https://doi.org/10.1111/cea.13212

\section{General rights}

Copyright and moral rights for the publications made accessible in the public portal are retained by the authors and/or other copyright owners and it is a condition of accessing publications that users recognise and abide by the legal requirements associated with these rights.

- Users may download and print one copy of any publication from the public portal for the purpose of private study or research.

- You may not further distribute the material or use it for any profit-making activity or commercial gain

- You may freely distribute the URL identifying the publication in the public portal

If you believe that this document breaches copyright please contact us providing details, and we will remove access to the work immediately and investigate your claim 
DR JEPPE MADURA LARSEN (Orcid ID : 0000-0003-1492-0708)

Article type : Unsolicited Review

\title{
Animal models of allergen-specific immunotherapy in food allergy: Overview and opportunities
}

\author{
Jeppe Madura Larsen ${ }^{1}$ and Katrine Lindholm B $\varnothing \mathrm{gh}^{1}$ \\ ${ }^{1}$ National Food Institute, Technical University of Denmark, Kgs. Lyngby, Denmark \\ Running title: Therapeutic animal models in food allergy
}

Keywords: Animal models, Food allergy, Immunotherapy, Desensitization, Tolerance induction

Corresponding Author: Jeppe Madura Larsen, National Food Institute, Technical University of Denmark, DK-2800 Kgs. Lyngby, Denmark. E-mail: jeml@food.dtu.dk. Phone: +45 9351 3485, Fax: +453588 7001 .

\author{
Abbreviations \\ APC: Antigen Presenting Cell \\ CMP: Cow's milk protein \\ CT: Cholera toxin \\ dNL: Draining lymph node \\ EP: Epicutaneous \\ EPIT: Epicutaneous Immunotherapy \\ HK: Heat-killed \\ ID: Intradermal \\ IG: Intragastric \\ IN: Intranasal \\ IP: Intraperitoneal \\ IPIT: Intraperitoneal Immunotherapy \\ IT: Immunotherapy \\ IV: Intravenous \\ $\mathrm{mLN}$ : Mesenteric lymph node \\ PR: Per rectum \\ SC: Subcutaneous
}

This article has been accepted for publication and undergone full peer review but has not been through the copyediting, typesetting, pagination and proofreading process, which may lead to differences between this version and the Version of Record. Please cite this article as doi: $10.1111 /$ cea. 13212

This article is protected by copyright. All rights reserved. 
SCIT: Subcutaneous immunotherapy

SLIT: Sublingual IT

Treg: Regulatory T cell

\section{Abstract}

Food allergy is an adverse reaction to otherwise harmless proteins in food. The disease is a major health problem of growing concern, affecting approximately $5-8 \%$ of young children and $2-4 \%$ of adults. No accepted strategy exists for prevention and treatment of food allergy, and strict avoidance of the offending food is presently the only viable management option. Living with food avoidance may have a huge impact on the quality of life of food allergic patients, with daily fear of serious or even fatal reactions. The urgent need for safe and efficient food allergy treatment options has led to massive research efforts to develop and improve strategies for food allergy immunotherapeutic approaches. A first step in developing new and improved strategies of immunotherapy often involves the use of animal models. In present review, we provide an overview of animal studies of allergen-specific immunotherapy highlighting opportunities and challenges for each approach. The presented models, almost exclusively performed in mice, assess therapeutic efficacy and immunological outcomes following oral, intraperitoneal, subcutaneous, epicutaneous, and sublingual administration of native allergens, or preparations of hydrolyzed allergen, $\mathrm{T}$ cell directed peptides, or allergen with immunomodulatory adjuvants. Recently, approaches using immune cell therapy have demonstrated efficacy. Current models mainly assess anaphylaxis as the primary clinical outcome. With the increased appreciation that food allergy is a heterogeneous disease presenting different phenotypes, there is a continued need to develop new disease-relevant therapeutic models of food allergy.

\section{Introduction}

Food allergy is an immune mediated hypersensitivity to specific proteins in food, which occur as a result of allergic sensitization due to a failure of the immune system to develop tolerance after first exposure, or the abrogation of an already established tolerance. The prevalence

This article is protected by copyright. All rights reserved. 
of food allergy is estimated to be around $5-8 \%$ in young children and around $2-4 \%$ in adults in the Western world [1], and appears to be a rising problem [1,2]. Most cases of food allergy is mediated by IgE-dependent immediate hypersensitivity reactions, however some rarer food allergies may also involve cell-mediated sensitization with and without the contribution of IgE (extensively reviewed in $[3,4])$. Ingestion of disease-triggering foods in sensitized individuals can cause an array of symptoms in the gastrointestinal tract (pain, nausea, vomiting and diarrhea), skin (itchiness, urticarial and angioedema), respiratory and cardiovascular systems (dyspnea, wheezing, and tachycardia) [5]. In severe cases allergic reactions can cause acute respiratory and cardiac arrest. The first line of management involves food-avoidance, and acute systemic reactions are treated with epinephrine, which are often carried by patients with severe allergy in case of accidental ingestion. The lack of treatment options, restrictive food-avoidance, and the prospect of accidental ingestion makes food allergy a chronic disease that significantly impacts the quality-of-life for patients [6].

Allergen-specific immunotherapy (IT) is emerging as a viable option for human desensitization with the ability to increase thresholds of reactivity, as demonstrate by a recent systematic meta-analysis of 31 clinical trials in food allergy [7]. However, current immunotherapeutic regimens are typically lengthy with repeated, increasing doses of allergen, and the risk of acute adverse reactions. Furthermore, current regimens are largely unable to induce complete clinical tolerance. Thus there is a need to develop better regimens of allergen-specific IT. Testing therapies in animal disease models is central to evaluating the potential of new immunotherapeutic strategies or modified versions of current regimens. Here we present a comprehensive overview of animal models of food allergy therapy currently reported in the literature, and highlight opportunities for new avenues of study and model improvements. This review will primarily address IT in animal models using allergens and allergen-challenges of relevance to clinical food allergy outcomes. A detailed overview of the presented therapeutic animal models can be found in table 1 , and summarized in figure 1. Currently most models have been developed in mice exploring oral therapy

This article is protected by copyright. All rights reserved. 
with dosaging of native protein, and to some extent less allergenic preparations containing hydrolyzed allergen and immunodominant T cells epitopes. Models using epicutaneous (EPIT) or subcutaneous immunotherapy (SCIT) has in recent years received increased attention due to possible better safety and efficacy of these routes compared to oral administration. Additionally, models exploring therapy using immunomodulatory adjuvants or cell therapy have been developed. Current studies have addressed several immunological and clinical outcomes of therapy (summarized in figure 2). However, most models only assess the acute anaphylaxis outcome of food allergy by temperature loss and clinical severity scoring. With the increased appreciation that food allergy is a heterogeneous disease presenting with different phenotypes and mechanisms in relation to foods, exposure, symptoms, and natural history [8], there is a continued need to develop new disease-relevant therapeutic models in food allergy.

\section{Oral immunotherapy}

The default outcome of ingesting food is for the immune system to tolerate the exposure to the foreign antigens contained within. The concept of oral tolerance has been studied in rodents since 1910, with early studies describing how oral ingestion of antigen would inhibit later experimental hyperactivity, thus demonstrating that tolerance to ingested food involves active antigen-specific suppression of hypersensitivity [9]. Several later studies have addressed the mechanistic basis of oral tolerance, including a pivotal role of regulatory T cells (reviewed in $[10,11])$. Oral IT (OIT) models have been developed using egg white [12], ovomucoid (native or heated) [12], ovalbumin [13], cow's milk proteins $[14,15]$ and peanut [15-17] in sensitized mice. In these studies therapy were able to reverse or ameliorate food challenge-induced anaphylaxis and clinical disease scores, when mice were challenged immediately after treatment. However some studies found $[12,13,17]$, that the desensitization was short-term as sensitization returned within $2-5$ weeks after therapeutic cessation. These findings are in line with oral immunotherapy trials in humans reporting limited effects on the induction of sustained unresponsiveness in food allergic individuals. The OIT

This article is protected by copyright. All rights reserved. 
models found varying effect on the levels of allergen-specific IgG reporting similar [12-14], decreased [17], or increased [15] IgG1 levels, and similar [12-14] or increased [13,15,16] IgG2a levels. The therapeutic effect on allergen-specific IgE levels were similarly diverse with similar $[13,15]$, increased [12] or decreased $[14,16,17]$ levels reported. These findings could be attributed to the dynamic nature of Ig levels during IT, and are in line with studies in humans reporting different Ig patterns depended on IT efficacy and duration $[18,19]$. Interestingly, the studies in ovalbuminsensitized mice observed sustained systemic allergen-specific humoral immune responses after therapy, as demonstrated by basophil activation assays and peritoneal mast cells activation $[12,13]$. Thus the mice was shown to be desensitized when orally challenged with allergen, but anaphylaxis could be induced by systemic allergen-challenge [12]. Similar results were observed in another study where peanut and whey OIT suppressed mast cell responses following oral challenge, but only mice receiving peanut OIT were protected from intraperitoneal (IP) induced anaphylaxis, indicating allergen-specific differences in therapeutic outcomes and mechanisms [15]. The therapeutic suppression of local gastrointestinal allergic responses was proposed to be mediated by increased IgA levels induced by treatment; however this hypothesis remains to be formally investigated [12]. Oral therapy was also associated with increased gastrointestinal permeability and changes in transcriptional profile in proximal jejunum [12]. The significance of these treatment-induced changes remain to be investigated, but may reflect the adverse gastrointestinal effects reported in human clinical trials.

Allergen-specific ex vivo production of T cell related type-2 cytokines (IL-4, IL-5 and/or IL-13) were suppressed after egg [12], cow's milk protein [14,15] and peanut [16] OIT, indicating suppression of systemic effector T cell immune responses. Indeed the studies found increased numbers of $\mathrm{CD}^{+}{ }^{+} \mathrm{CD} 25^{+} \mathrm{FoxP}^{+}$regulatory $\mathrm{T}$ cells in the intestine or $\mathrm{mLN}$ in response to milk protein $[14,15]$ or peanut $[16]$ therapy. The induction of intestinal regulatory T cells was associated with increased tissue expression of regulatory effector cytokines TGF- $\beta$ and IL-10 [14]. Unexpectedly, IT in 
ovalbumin-sensitized mice did not result in the generation of $\mathrm{CD}^{+} \mathrm{CD} 25^{+} \mathrm{FoxP} 3^{+}$regulatory $\mathrm{T}$ cells [13], and ex vivo allergen-specific IL-10 was suppressed in mice receiving OIT [12]. These results suggest the induction of different immune regulatory mechanisms in the therapeutic response to different allergens or regimens. The study using peanut IT [16] found, that the expansion of regulatory $\mathrm{T}$ cells was abrogated eight weeks post-therapy, and the induced regulatory $\mathrm{T}$ cells were unable to transfer desensitization to sensitized mice. These findings suggest that the short-term desensitization in these models is due to the unstable induction of regulatory T cells. Interestingly, a study combining peanut OIT and abrogation of IgE signaling by anti-IgE antibody or Syk inhibitor administration in allergy-prone $\| 4$ raF709 (gain-of-function mutation in the IL-4 receptor $\alpha$ chain) mice found induction of sustained unresponsiveness associated with expansion of regulatory T cells and suppression of allergen-specific Th2 cells [17]. These findings are in line with recent studies in humans, where anti-IgE can facilitate accelerated desensitization by oral dosing of allergen [20]. Combined, the studies presented here suggest that induction of allergen-specific regulatory $T$ cells is pivotal for efficient IT of food allergy, and different allergens and therapeutic regimens may induce regulatory $T$ cells with different phenotypes. There is a need to study co-administration of immune modulatory reagents (TLR agonists and biologicals) in OIT models, and some examples are discussed later in the review.

\section{Intraperitoneal immunotherapy}

The studies presented above performed IT to food proteins via the oral route, however a couple of studies have used intraperitoneal (IP) injections with tree nut (cashew and walnut) protein extracts as a model of oral therapy [21,22]. Cashew intraperitoneal IT (IPIT) was able to abrogate allergic reactions in response to cashew [21] or pistachio [22] (due to cross-reactivity) in cashew-sensitized mice. Furthermore, cashew-, walnut- or combined-IT was able to ameliorate anaphylaxis (temperature loss) and clinical disease presentation in cashew and walnut dualsensitized mice due to cross-reactivity between these three nuts [22]. IT was associated with

This article is protected by copyright. All rights reserved. 
increased allergen-specific IgG1 [21,22], IgG2 [21] and suppression of T cell related type-2 cytokine release (IL-4, IL-5 and IL-13) [21,22] by splenocytes. Interestingly, in these models challenges were performed IP 2-5 weeks post-treatment indicating long-term efficacy of therapy. These findings are opposed to the studies of OIT reviewed above, in which efficacy to oral challenges was lost 2-4 weeks post-treatment and allergic reactivity was sustained in response to IP (systemic) challenge for ovalbumin and whey OIT $[12,15]$. This indicates that the therapeutic tolerance induced via the oral route is different from tolerance generated via IP allergen administration. It could be speculated that oral allergen administration subverts long-term protection by chronic activation of IgE-dependent mechanisms, as indicated in the case of oral peanut desensitization in combination with anti-IgE [17]. However, more experimental work comparing administration routes using the same allergens, sensitization and challenge protocols are required to address this hypothesis. Furthermore, the role of regulatory T cells in IPIT models remains to be investigated.

\section{Immunotherapy using hydrolyzed food proteins}

It is generally accepted, that hydrolyzed food allergens exhibit lower allergenicity due the destruction of allergenic epitopes. It has been demonstrated, that pepsin-digested cashew protein extracts elicit a reduced anaphylactic response (temperature loss and symptom score) compared to undigested protein in a murine food allergy model using IP or oral sensitization to undigested cashew protein [21]. Both digested and undigested cashew protein were show to have similar allergenicity by inducing comparable IgE- and Th2-responses, and clinical anaphylaxis following challenge in mice sensitized to the respective preparations using adjuvant. These observations demonstrate the principle, that IT using digested protein has reduced potential to elicit an allergic response during therapy to native food protein. The study continued to use digested cashew protein as IPIT in mice sensitized to undigested cashew protein [21]. IT was demonstrated to abrogate anaphylaxis when the mice were challenged with undigested protein. Furthermore, therapy was associated with the induction of allergen-specific IgG1 and IgG2a, as well as suppression

This article is protected by copyright. All rights reserved. 
of IL-5 and IL-13 production by splenocytes. The clinical and immunological outcomes were comparable to mice receiving IPIT using undigested protein extract, indicating the same mechanism of desensitization. OIT using hydrolyzed egg white proteins in egg white sensitized mice was indicated to ameliorate anaphylaxis as demonstrated by normalizing serum histamine levels following challenge [23]. Therapy was associated with a modest reduction in allergen-specific IgE and IgG2a, whereas IgG1 was unchanged. Allergen-stimulated splenocytes demonstrated reduced systemic Th1 (IFN- $\gamma$ ) and Th2 (IL-4) responses. Furthermore, expression of Th1 and Th2 effector cytokines (IFN- - , IL-12p40, IL-4 and IL-13) was reduced in intestinal tissue; however IL-18 and IL-5 were increased. Therapy was found to promote expression of immune regulatory genes TGF- $\beta$ and FoxP3 but suppress IL-10 in intestinal tissue, suggesting the generation of regulatory T cells in therapy using digested allergens. As discuss in previous sections, IPIT and OIT may elicit different mode of desensitization, and oral therapy may give rise to specific gut protection and adverse reactions depended on the allergen $[12,15]$. Thus, OIT using digested and undigested protein needs to be compared head-to-head to determine altered efficacy, reduced adverse effects and mechanism of desensitization.

\section{T cell directed peptide immunotherapy}

IT using specific peptides may be a more specific alternative to the use of digested or hydrolyzed food proteins allowing a consistent and well-defined therapy. Several studies have systematically assayed specific peptides from allergens to identify T cell epitopes by the means of stimulating immune cells from sensitized animals or allergic patients followed by measuring proliferation or cytokine production. Allergen immunodominant T cell epitopes have been identified for several food allergens for mice (ovalbumin [24], ovomucoid [25], beta-lactoglobulin [26,27], and shrimp tropomyosin [28]) and human (peanut Ara h 1 [29,30] and Ara h 2 [31,32], and shrimp tropomyosin [33]). Oral administration of murine immunodominat peptides have been shown to ameliorate or reverse anaphylaxis, disease scores and/or diarrhea in mice sensitized to ovalbumin

This article is protected by copyright. All rights reserved. 
[34], ovomucoid [35], shrimp tropomyosin [28], and beta-lactoglobulin [36]. The studies of ovomucoid and beta-lactoglobulin reported a therapeutic effect of single peptide administration (15and 22-mers) $[35,36]$, whereas none of three different peptides (15-mers) in the ovalbumin study had an effect when administered individually [34]. However, administration of the three ovalbumin peptides as a cocktail significantly ameliorated clinical anaphylactic scores and systemic histamine levels, suggesting varying efficacy of different $\mathrm{T}$ cell epitopes. The study in shrimp-tropomyosin sensitized mice compared a cocktail of six immunodominant and six non-immunodominat peptides (20-mers) demonstrating specific efficacy of immunodominant peptide IT [28]. Therapy directed against ovalbumin [34], ovomucoid [35] or shrimp-tropomyosin [28] reported decreased allergenspecific IgE levels and suppression of type-2 immune responses (IL-4, IL-5 and IL-13) in the intestine or following ex vivo stimulation. Additionally, these studies found therapeutic induction of immune regulatory mechanisms indicated by increased intestinal expression of FoxP3, TGF- $\beta$ and/or IL-10 $[28,34]$, as well as increased allergen-specific IL-10 production and systemic CD4 ${ }^{+}$FoxP3 $^{+}$regulatory $\mathrm{T}$ cell numbers [35]. The study using peptide IT in beta-lactoglobulin sensitized mice was unable to report therapeutic effects on antibody levels (allergen-specific $\lg E, \lg G 1, \lg G 2 a$, $\lg A$, or total $\lg E$ ), allergen-specific immune responses ex vivo (IL-10, IFN- - , IL-10, and IL-12), or splenic $\mathrm{CD}^{+} \mathrm{CD} 25^{+} \mathrm{FoxP}^{+}$regulatory $\mathrm{T}$ cell numbers, suggesting different mode of action or experimental difficulties in this study [36].

OIT using immunodominant peptides show therapeutic potential, but long-term efficacy remains to be studied in these pre-clinical models. Unfortunately, recent clinical trials using Fel d 1 peptide therapy in humans have been disappointing in terms of therapeutic effect (Circassia Pharmaceuticals plc, June $20^{\text {th }} 2016$ press release, www.circassia.com). This may be attributed to the need for immunodominant peptides that could be different among patients due to genetic HLA diversity. Indeed, systematic screening reveal different peptide epitopes among different mouse stains for ovomucoid [25] and beta-lactoglobulin [26,27].

This article is protected by copyright. All rights reserved. 


\section{Subcutaneous immunotherapy}

Administrating IT via other routes than oral may elicit different clinical and immunological outcomes when the food allergy expressing organ is not targeted directly. Subcutaneous (SC) injections have for decades been used in IT of allergic disease with demonstrated efficacy in asthma, rhinitis, and venom allergies [37]. However, the use of subcutaneous IT (SCIT) in food allergy was likely abandoned in the 1990s due to high rates of adverse systemic reactions in peanut allergic patients $[38,39]$. A recent study compared SCIT and OIT in models of cow's milk (whey) and peanut allergy [15]. SCIT and OIT were able to suppress anaphylaxis and mast cell degranulation (serum mMCP-1) following intragastric (IG) or intradermal (ID) challenge in both models with no clear differences in route-dependent efficacy. Rather, clinical allergen-dependent differences were indicated by the observation that neither SCIT nor OIT could protect from IP induced anaphylaxis in whey sensitized mice, but peanut sensitized mice were protected in a therapeutic dose-dependent manner. Both SCIT and OIT increased serum allergen-specific IgG1 and IgG2a, whereas only SCIT increased allergen-specific IgE. This may be in line with the observation, that only OIT suppressed (whey) or had similar (peanut) allergen-specific type-2 cytokines production (IL-5 and IL-13) while SCIT was similar (whey) or increased (peanut). The authors addressed the frequency of $\mathrm{CD}_{4}^{+} \mathrm{CD} 69^{+} \mathrm{ST} 2^{+} \mathrm{Th} 2, \mathrm{CD}^{+} \mathrm{CD} 69^{+} \mathrm{CXCR}^{+}$Th1 and $\mathrm{CD}^{+} \mathrm{CD} 25^{+} \mathrm{FoxP} 3^{+}$ regulatory T cells in spleen or $\mathrm{mLN}$, however no clear allergen- or therapy-related patterns could be observed suggesting diverse underlying immunological mechanisms [15]. Other SCIT mouse models using food allergens support efficacy, but have been conducted without oral or IP allergen provocations for the assessment of clinical food allergy outcomes. Studies using ovalbumin or peanut SCIT found therapy to suppress allergen-specific IgE and increase IgG2a in serum [40,41]. In line, SCIT treated animals exhibited decreased airway hyperreactivity and suppressed type-2 immune responses in the lung following airway allergen challenge. Additional mechanistic studies in SCIT models employing clinical food allergy-related outcomes are needed, including therapeutic duration, and adverse reactions compared to OIT.

This article is protected by copyright. All rights reserved. 


\section{Epicutaneous immunotherapy}

Epicutaneus IT (EPIT) has recently emerged as a new mode of allergen delivery in food

allergy therapy. It was hypothesized that applying allergen onto intact skin would allow controlled diffusion, and reduce risk of systemic allergen dissemination and anaphylaxis. To this end, DBV Technologies developed an epicutaneus delivery system (Viaskin patch) that consists of a chamber that releases allergen onto the skin [41], where it diffuses into the epidermis and is taken up by dendritic cells that migrates to draining lymph nodes and induce allergen-specific regulatory $T$ cells [42]. Early studies found that EPIT could suppress allergen-specific IgE and type-2 immune responses, and increase allergen-specific IgG2a in ovalbumin [41,42], peanut [40,41], cow's milk protein [43], house dust mite [41] and pollen [41,44] sensitized mice. The first studies of EPIT in relation to food allergy outcomes were conducted in models of esophago-gastro-enteropathy following long-term allergen exposure in sensitized animals. EPIT was found to completely reverse esophageal and gastric eosinophilia, and reduce serum allergen-specific IgE in peanut sensitized mice $[45,46]$ and pigs [47]. Abrogated eosinophilia was associated with reduced eotaxin (CCL11) in mice esophagus and pig splenocytes. Furthermore, EPIT suppressed systemic allergen-specific type-2 (IL-5 and IL-13) immune responses in the models. The studies in mice reported increased $\mathrm{CD}^{+} \mathrm{CD} 25^{+} \mathrm{FoxP}^{+}$regulatory T cells expressing CTLA-4, but not PD-1 or IL-10 in the spleen following EPIT [46]. The EPIT-induced regulatory $T$ cells were found to suppress esophageal eosinophilia, eotaxin and IL-5 expression when adoptively transferred into non-treated peanut-sensitized animals. The regulatory T cells exhibited a stable phenotype as cells adoptively transferred from mice 8 weeks post-treatment retained the suppression of allergen-induced esophageal eosinophilia and systemic type-2 (IL-5 and IL-13) immune responses. These findings are supported by a more recent study demonstrating long-term stability of EPIT induced, but not OIT or sublingual IT (SLIT) induced, regulatory T cells [16]. EPIT-induced regulatory T cells were found to specifically express CCR9, CLA, CCR6, CCR3 and CCR8, suggesting that these cells can migrate and suppress allergic responses in several peripheral tissues, including the gut and skin. Interestingly, transfer of EPIT induced

This article is protected by copyright. All rights reserved. 
regulatory $T$ cells was found to expand the endogenous regulatory $T$ cell population in recipient mice [46], which may explain why EPIT to cow's milk proteins suppress later sensitization to peanut and house dust mite in mice [43].

A recent study reported the therapeutic involvement of EPIT-induced regulatory $T$ cells in a model of acute ovalbumin-induced anaphylaxis [13]. In this study did EPIT, but not OIT, induce long-term ( $>5$ weeks) protection against anaphylaxis following oral challenge in ovalbuminsensitized mice. Interestingly, humoral allergen-specific responses were not affected by treatment as demonstrated by basophil activation test and passive sensitization of naïve animal. Rather, allergenspecific CD4 ${ }^{+}$LAP $^{+}$FoxP3 $3^{-}$regulatory $T$ cells expressing CCR9, CCR6 and CCR4 were found to be induced in response to EPIT, but not OIT. These cells were induced in skin-draining lymph nodes and migrated to $\mathrm{mLN}$ and gut lamina propria. Adoptive transfer and cytokine blocking experiments in passively sensitized mice indicated that EPIT-induced regulatory $T$ cells suppress mast cell activation in a TGF- $\beta$ dependent manner.

The findings in EPIT models demonstrate that EPIT-induced regulatory T cells have a stable and distinct phenotype compared to regulatory $T$ cells induced via other routes. Clinical trials in humans have shown that EPIT is safe, however the current strategies have demonstrated limited efficacy [48]. Further technical improvements of EPIT delivery, including skin preparation and delivery matrix, are open for optimization and mechanistic exploration in animal models of food allergy.

\section{Sublingual immunotherapy}

Sublingual IT (SLIT) involves administration of allergen under the tongue followed by swallowing. This therapeutic route is commonly used in the treatment of allergic rhinitis and asthma with demonstrated efficacy in humans [49]. Clinical trials of SLIT in food allergy has been conducted

This article is protected by copyright. All rights reserved. 
in humans, but indicated reduced efficacy in the treatment of peanut and cow's milk allergy compared to OIT [50,51]. To our knowledge, only one therapeutic animal model using SLIT in relation to food allergy outcomes has been published. The study was published very recently demonstrating clinical efficacy of SLIT in cow's milk sensitized mice using low dosages of allergen (pg to ng range) [52]. Therapy was associated with increased IL-10 and TGF- $\beta$ levels in jejunum indicating a role of regulatory $T$ cells. This is supported by the study mentioned earlier comparing the function and phenotype of regulatory T cells induced by SLIT, EPIT and OIT in peanut sensitized mice [53]. No marked therapeutic difference was observed between allergen administration routes in relation to increased allergen-specific IgG2a in serum and suppression of allergen-specific type-2 (IL-5 and IL-13) cytokines. SLIT and OIT did however increase allergen-specific IL-10 production compared to EPIT, which in the SLIT group was essential for the suppression of allergen-specific IL-5 and IL-13 ex vixo. These findings indicate that SLIT induces IL-10 producing regulatory Tr1 cells in this peanut model. The study further indicated that the SLIT-induced regulatory Tr1 cells were unstable, as regulatory T cells adoptively transferred 8 weeks post treatment to sensitized animals had lost the ability to suppress allergic esophageal eosinophilia and allergen-specific immune responses. Development of new SLIT food allergy animal models may further our understanding of the immunological mechanism of SLIT in this disease, and allow optimization of administration protocols and allergen formulation.

\section{Immunotherapy using immunomodulatory adjuvants}

Adjuvants are commonly used in vaccines to elicit a desired immunological response.

Therapeutic studies in food allergy models have explored the ability of adjuvants to skew the allergic type-2 immune response towards a type-1 response using TLR9 agonists [54-57] or heat-killed (HK) bacteria [58,59]. Two of the studies using TLR9 agonists were performed in mice sensitized to peanut using OIT [56] with whole peanut or peanut protein extract $[54,55]$. The studies addressing the role of $\mathrm{HK}$ bacterial adjuvants were performed using subcutaneous or per rectum (PR) IT using

This article is protected by copyright. All rights reserved. 
recombinant Ara h 1-3 proteins with modified epitopes reducing IgE binding in peanut sensitized mice $[58,59]$. The studies reported similar results with suppression of oral challenge-induced anaphylaxis, reduced allergen-specific IgE and increased IgG2a in groups receiving adjuvant allergenspecific therapy. Allergen-specific type-2 (IL-4, IL-5 and IL-13) immune responses were suppressed, whereas IFN- $\gamma$ was increased. Similar results was obtained in a IPIT study in peanut sensitized mice comparing the action of class A, B, and C CpG-ODN TLR9 agonists, where therapeutic effect was reported for class B and C CPG-ODNs indicating that B cells are a target of TLR9 agonism [56]. Two studies performed several oral challenges indicating therapeutic efficacy for up to 10-16 weeks post treatment $[55,59]$. Combined, these findings indicate that Th1-driving adjuvants promote allergenspecific Th1 cells with a stable phenotype. Another study using TLR9 agonist in intradermal IT in ovalbumin sensitized mice found limited effect on anaphylaxis scores and temperature loss, but indicated improved survival following challenge [57]. This finding may indicate allergen-specific differences, or reflect different treatment regimens. The role of regulatory $T$ cells in these models remains largely unknown. One study using TLR9 agonist found no therapeutic effect on allergenspecific TGF- $\beta$ levels [55], whereas one model using HK bacterial reported increased allergen-specific TGF- $\beta$ [59]. As HK bacteria contain several ligands stimulating innate immunity, it cannot be excluded that agonists targeting other pathogen-associated molecular pattern receptors than TLR9 can be involved in promoting regulatory T cells. Thus there is an opportunity to study the role of other adjuvants in these models to identify alternatives to complex whole bacterial adjuvants contain several unknown components and antigens. Additionally, targeting the gut microbiota composition using probiotics or prebiotics may be an option to modulate local immune responses. Administration of a mixture of probiotic bacteria to shrimp tropomyosin sensitized mice has previously been found to suppress type-2 immune responses and challenge-induced anaphylaxis [60]. Thus, combining probiotics and allergen-specific IT may lead to improved efficacy.

This article is protected by copyright. All rights reserved. 
A recent study employed a synthetic cetylpyridinium chloride and oil based nanoemulsion adjuvant with type-1/17 driving properties for nasal peanut IT in mice [61]. The adjuvant was found to promote suppression of challenge-induced anaphylaxis, allergen-specific IgE, and type-2 (IL-4, IL-5, IL-33) immune responses, while increasing IgG2a and IgG2b and regulatory T cells. The induction of therapeutic efficacy was partly dependent on IL-10 highlighting an underlying role of immunoregulatory mechanisms in this type of adjuvant. The importance of enhancing immunoregulatory mechanisms during allergen-specific IT is further supported by a recent study combining SLIT and the expansion of regulatory T cells using IL-2/anti-IL-2Ab complexes in cow's milk sensitized mice [52].

An interesting study used peanut protein chemically coupled to syngeneic splenic leukocytes as intravenous (IV) IT in peanut sensitized mice [62]. The chemical linking induces apoptosis in leukocytes making the cells a therapeutic vehicle and adjuvant in allergen-specific IT. Previous studies suggest that the apoptotic leukocytes are taken up by splenic marginal zone APCs leading to the induction of clonal anergy and regulatory T cell specific for the coupled antigen. IT in peanut sensitized mice was found to reverse challenge-induced blood eosinophilia and suppress allergen-specific type-2 (IL-4 and IL-13) responses, but had only a week effect on anaphylactic scores. This IT approach may need optimization in terms of chemical linking, cell subsets, and control of apoptosis/necrosis. Other vehicles for allergen could be explored for IV administration, including synthetic particles, coupling to APC-receptor specific targets, and allergen complexes.

\section{Cellular immunotherapy}

IT using immune cells has been used in the clinic to promote anti-cancer immunity, commonly by administrating ex vivo expanded effector T cells or dendritic cells carrying cancer antigens [63]. To our knowledge, cellular IT has not been applied in clinical allergy, which likely is reflected by the very few studies of this therapeutic approach in food allergy animal models. The

This article is protected by copyright. All rights reserved. 
generation and transfer of allergen-specific regulatory $T$ cells could be a potential therapy. This was recently explored in a model of peanut allergy where mice received regulatory $T$ cells from mice having received OIT, SLIT or EPIT with peanut [16]. The study found that EPIT-induced regulatory T cells could suppress the elicitation of esophageal eosinophilia. Although the main objective was to assess the phenotypic stability of regulatory $T$ cells induced by various routes of $I T$, this study provides a model of exploring this type of IT.

Dendritic cells play a central role in instructing $T$ cell responses based on molecular signals from pathogens and other environmental stimuli. A recent study exploited that retinoic acid stimulates the development of a tolerogenic dendritic cell phenotype (RA-DCs). RA-DCs was generated in vitro and pulsed with ovalbumin or peanut protein before being administrated IP to sensitized mice [64]. RA-DC therapy suppressed challenge-induced anaphylaxis and diarrhea in both models. Therapeutic efficacy was dependent on IL-27 production by the RA-DCs, and in vitro experiments found that RA-DCs stimulated the development of IL-10 producing regulatory $\mathrm{CD}^{+} \mathrm{LAG3}^{+} \mathrm{CD}_{49 b^{-} \text {FoxP3 }}^{-} \operatorname{Tr} 1$ cells. Mechanistically the study indicated that the RA-DCs could suppress allergen-specific Th2 cells via IL-10 and TGF- $\beta$ production, while IL-27 converted Th2 cells into regulatory $\operatorname{Tr} 1$ cells.

Cellular IT is in its infancy within food allergy, and inspiration could be taken from the experiences in the field of autoimmunity, which aims to suppress the pathological Th1/17 response and promote regulatory T cells [65]. Models using other immune cell phenotypes for therapy, as well as optimizing the approach in terms of cell preparation, route of delivery, and adjuvants may be needed.

This article is protected by copyright. All rights reserved. 


\section{Conclusion}

Animal models of food allergen-specific IT are widely used as a preclinical approach to study the efficacy of new therapeutic strategies. As reviewed here, animal models have been used as a first screen of the applicability of different routes of administration, the use of modified version of allergens, and the use of combining allergen with non-specific immune modulation. Efficacy has mostly been evaluated by means of anaphylactic scores, while the therapeutic mechanisms have primarily been associated of the induction of regulatory $T$ cells, changes in allergen-specific antibody levels, and suppression of Th2-related cytokines. Only few of the reported studies use experimental techniques to ascertain causal therapeutic mechanisms, including the use of signal blocking, cell depletion and transfer experiments, and gene knock-out mice. Thus, there remain opportunities for in-depth mechanistic studies of the induction and maintenance of immunological tolerance in these models. As no allergen-specific immunotherapeutic approaches has yet been accepted in food allergy, animal models may play a valuable tool in addressing safety and efficacy, and to compare different approaches in a controlled environment. Animal models have the unique potential to allow the study of the efficacy of a given approach with different allergens, as well as the in-depth study of mechanisms underlying an immunotherapeutic effect. With the rising appreciation that food allergy is a heterogeneous disease [8] future models should include other disease-relevant clinical outcomes in addition to acute anaphylaxis, including diarrhea, respiratory function and gastrointestinal pathology. Intriguingly, the models presented underline a possible role of allergen-specific differences in therapeutic outcomes, mechanisms, and even sensitization. In line, the skin has been indicated as a route of sensitization for which models has recently been developed [13]. It remains however largely unknown how the route (oral, IP, skin, or respiratory) or method of sensitization (adjuvant use, or genetically susceptible mice) affect therapeutic outcomes in the presented IT models. Animal models will in the future remain a valuable tool to study efficacy and mechanisms in different food allergy phenotypes in a controlled manner.

This article is protected by copyright. All rights reserved. 


\section{Conflict of Interest}

The authors declares no conflicts of interest in the publication of this review.

\section{Acknowledgement}

This work is part of the ALLEVIATE project funded by Innovation Fund Denmark.

\section{References}

1. Sicherer SH, Sampson HA. Food allergy: Epidemiology, pathogenesis, diagnosis, and treatment. J Allergy Clin Immunol 2014;133:291-307; quiz 308.

2. Prescott SL, Pawankar R, Allen KJ, Campbell DE, Sinn JK, Fiocchi A et al. A global survey of changing patterns of food allergy burden in children. World Allergy Organ J 2013;6:21.

3. Nowak-Wegrzyn A, Szajewska H, Lack G. Food allergy and the gut. Nat Rev Gastroenterol Hepatol 2016;14:241-257.

4. Yu W, Freeland DMH, Nadeau KC. Food allergy: immune mechanisms, diagnosis and immunotherapy. Nat Rev Immunol 2016;16:751-765.

5. Longo G, Berti I, Burks AW, Krauss B, Barbi E. IgE-mediated food allergy in children. Lancet 2013;382:1656-1664.

6. Greenhawt M. Food allergy quality of life and living with food allergy. Curr Opin Allergy Clin Immunol 2016;16:284-290.

7. Nurmatov U, Dhami S, Arasi S, Pajno GB, Fernandez-Rivas M, Muraro A et al. Allergen immunotherapy for IgE-mediated food allergy: a systematic review and meta-analysis. Allergy Published Online First: 11 May 2017. doi:10.1111/all.13124

8. Deschildre A, Lejeune S, Cap M, Flammarion S, Jouannic L, Amat F et al. Food allergy phenotypes: The key to personalized therapy. Clin Exp Allergy 2017;47:1125-1137.

9. Brandtzaeg P. History of oral tolerance and mucosal immunity. Ann N Y Acad Sci 1996;778:1-

This article is protected by copyright. All rights reserved. 
27.

10. Vickery BP, Scurlock AM, Jones SM, Burks AW. Mechanisms of immune tolerance relevant to food allergy. J Allergy Clin Immunol 2011;127:576-584.

11. Pabst O, Mowat AM. Oral tolerance to food protein. Mucosal Immunol 2012;5:232-239.

12. Leonard SA, Martos G, Wang W, Nowak-Węgrzyn A, Berin MC. Oral immunotherapy induces local protective mechanisms in the gastrointestinal mucosa. J Allergy Clin Immunol 2012;129:1579-1587.e1.

13. Tordesillas L, Mondoulet L, Blazquez AB, Benhamou P-H, Sampson HA, Berin MC.

Epicutaneous immunotherapy induces gastrointestinal LAP+ regulatory T cells and prevents food-induced anaphylaxis. J Allergy Clin Immunol 2017;139:189-201.e4.

14. Smaldini PL, Orsini Delgado ML, Fossati CA, Docena GH. Orally-Induced Intestinal CD4+ CD25+ FoxP3+ Treg Controlled Undesired Responses towards Oral Antigens and Effectively Dampened Food Allergic Reactions. PLoS One 2015;10:e0141116.

15. Vonk MM, Wagenaar L, Pieters RHH, Knippels LMJ, Willemsen LEM, Smit JJ et al. The efficacy of oral and subcutaneous antigen-specific immunotherapy in murine cow's milk- and peanut allergy models. Clin Transl Allergy 2017;7:35.

16. Dioszeghy V, Mondoulet L, Puteaux E, Dhelft V, Ligouis M, Plaquet C et al. Differences in phenotype, homing properties and suppressive activities of regulatory $T$ cells induced by epicutaneous, oral or sublingual immunotherapy in mice sensitized to peanut. Cell $\mathrm{Mol}$ Immunol 2017;14:770-782.

17. Burton O, Noval Rivas M, Zhou J, Logsdon S, Darling A, Koleoglou K et al. Immunoglobulin E Signal Inhibition during Allergen Ingestion Leads to Reversal of Established Food Allergy and Induction of Regulatory T Cells. Immunity 2014;41:141-151.

18. Sugimoto $M$, Kamemura N, Nagao M, Irahara M, Kagami S, Fujisawa T et al. Differential response in allergen-specific IgE, IgGs, and IgA levels for predicting outcome of oral immunotherapy. Pediatr Allergy Immunol 2016;27:276-282.

This article is protected by copyright. All rights reserved. 
19. Wang J, Sampson HA. Oral and sublingual immunotherapy for food allergy. Asian Pacific J allergy Immunol 2013;31:198-209.

20. Andorf S, Purington N, Block WM, Long AJ, Tupa D, Brittain E et al. Anti-lgE treatment with oral immunotherapy in multifood allergic participants: a double-blind, randomised, controlled trial. lancet Gastroenterol Hepatol Published Online First: 11 December 2017. doi:10.1016/S2468-1253(17)30392-8

21. Kulis M, Macqueen I, Li Y, Guo R, Zhong X-P, Burks AW. Pepsinized cashew proteins are hypoallergenic and immunogenic and provide effective immunotherapy in mice with cashew allergy. J Allergy Clin Immunol 2012;130:716-723.

22. Kulis M, Li Y, Lane H, Pons L, Burks W. Single-tree nut immunotherapy attenuates allergic reactions in mice with hypersensitivity to multiple tree nuts. J Allergy Clin Immunol 2011;127:81-88.

23. Yang M, Yang C, Nau F, Pasco M, Juneja LR, Okubo T et al. Immunomodulatory effects of egg white enzymatic hydrolysates containing immunodominant epitopes in a BALB/c mouse model of egg allergy. J Agric Food Chem 2009;57:2241-2248.

24. Yang M, Mine Y. Novel T-cell epitopes of ovalbumin in BALB/c mouse: Potential for peptideimmunotherapy. Biochem Biophys Res Commun 2009;378:203-208.

25. Mizumachi K, Kurisaki J. Localization of T cell epitope regions of chicken ovomucoid recognized by mice. Biosci Biotechnol Biochem 2003;67:712-719.

26. Tsuji NM, Kurisaki J, Mizumachi K, Kaminogawa S. Localization of T-cell determinants on bovine beta-lactoglobulin. Immunol Lett 1993;37:215-221.

27. Totsuka M, Ametani A, Kaminogawa S. Fine mapping of T-cell determinants of bovine betalactoglobulin. Cytotechnology 1997;25:101-113.

28. Wai CYY, Leung NYH, Leung PSC, Chu KH. T cell epitope immunotherapy ameliorates allergic responses in a murine model of shrimp allergy. Clin Exp Allergy 2016;46:491-503.

29. Ramesh M, Yuenyongviwat A, Konstantinou GN, Lieberman J, Pascal M, Masilamani M et al. 
Peanut T-cell epitope discovery: Ara h 1. J Allergy Clin Immunol 2016;137:1764-1771.e4.

30. Prickett SR, Voskamp AL, Phan T, Dacumos-Hill A, Mannering SI, Rolland JM et al. Ara h 1 CD4+ T-cell epitope-based peptides: candidates for a peanut allergy therapeutic. Clin Exp Allergy 2013;43:684-697.

31. Prickett SR, Voskamp AL, Dacumos-Hill A, Symons K, Rolland JM, O'Hehir RE. Ara h 2 peptides containing dominant CD4+ T-cell epitopes: Candidates for a peanut allergy therapeutic. J Allergy Clin Immunol 2011;127:608-615.e5.

32. Pascal M, Konstantinou GN, Masilamani M, Lieberman J, Sampson HA. In silico prediction of Ara h 2 T cell epitopes in peanut-allergic children. Clin Exp Allergy 2013;43:116-127.

33. Ravkov E V, Pavlov IY, Martins TB, Gleich GJ, Wagner LA, Hill HR et al. Identification and validation of shrimp-tropomyosin specific CD4 T cell epitopes. Hum Immunol 2013;74:15421549.

34. Yang M, Yang C, Mine Y. Multiple T cell epitope peptides suppress allergic responses in an egg allergy mouse model by the elicitation of forkhead box transcription factor 3-and transforming growth factor- $\beta$-associated mechanisms. Clin Exp Allergy 2010;40:668-678.

35. Rupa P, Mine Y. Oral immunotherapy with immunodominant T-cell epitope peptides alleviates allergic reactions in a Balb/c mouse model of egg allergy. Allergy 2012;67:74-82.

36. Thang $\mathrm{CL}$, Zhao X. Effects of orally administered immunodominant T-cell epitope peptides on cow's milk protein allergy in a mouse model. Food Res Int 2015;71:126-131.

37. Pajno GB, Nadeau KC, Passalacqua G, Caminiti L, Hobson B, Jay DC et al. The evolution of allergen and non-specific immunotherapy: past achievements, current applications and future outlook. Expert Rev Clin Immunol 2015;11:141-154.

38. Oppenheimer JJ, Nelson HS, Bock SA, Christensen F, Leung DY. Treatment of peanut allergy with rush immunotherapy. J Allergy Clin Immunol 1992;90:256-262.

39. Nelson HS, Lahr J, Rule R, Bock A, Leung D. Treatment of anaphylactic sensitivity to peanuts by immunotherapy with injections of aqueous peanut extract. J Allergy Clin Immunol

This article is protected by copyright. All rights reserved. 
1997;99:744-751.

40. Mondoulet L, Dioszeghy V, Vanoirbeek JAJ, Nemery B, Dupont C, Benhamou P-H.

Epicutaneous Immunotherapy Using a New Epicutaneous Delivery System in Mice Sensitized to Peanuts. Int Arch Allergy Immunol 2011;154:299-309.

41. Mondoulet L, Dioszeghy V, Ligouis M, Dhelft V, Dupont C, Benhamou P-H. Epicutaneous immunotherapy on intact skin using a new delivery system in a murine model of allergy. Clin Exp Allergy 2009;40:659-667.

42. Dioszeghy V, Mondoulet L, Dhelft V, Ligouis M, Puteaux E, Benhamou P-H et al. Epicutaneous Immunotherapy Results in Rapid Allergen Uptake by Dendritic Cells through Intact Skin and Downregulates the Allergen-Specific Response in Sensitized Mice. J Immunol 2011;186:5629_ 5637.

43. Mondoulet L, Dioszeghy V, Puteaux E, Ligouis M, Dhelft V, Plaquet C et al. Specific epicutaneous immunotherapy prevents sensitization to new allergens in a murine model. J Allergy Clin Immunol 2015;135:1546-1557.e4.

44. Mondoulet L, Dioszeghy V, Ligouis M, Dhelft V, Puteaux E, Dupont C et al. Epicutaneous Immunotherapy Compared with Sublingual Immunotherapy in Mice Sensitized to Pollen ( Phleum pratense ). ISRN Allergy 2012;2012:1-8.

45. Mondoulet L, Dioszeghy V, Larcher T, Ligouis M, Dhelft V, Puteaux E et al. Epicutaneous Immunotherapy (EPIT) Blocks the Allergic Esophago-Gastro-Enteropathy Induced by Sustained Oral Exposure to Peanuts in Sensitized Mice. PLoS One 2012;7:e31967.

46. Dioszeghy V, Mondoulet L, Dhelft V, Ligouis M, Puteaux E, Dupont C et al. The regulatory T cells induction by epicutaneous immunotherapy is sustained and mediates long-term protection from eosinophilic disorders in peanut-sensitized mice. Clin Exp Allergy 2014;44:867-881.

47. Mondoulet L, Kalach N, Dhelft V, Larcher T, Delayre-Orthez C, Benhamou PH et al. Treatment of gastric eosinophilia by epicutaneous immunotherapy in piglets sensitized to peanuts. Clin

This article is protected by copyright. All rights reserved. 
Exp Allergy Published Online First: 20 October 2017. doi:10.1111/cea.13037

48. Senti G, Freiburghaus AU, Kundig TM. Epicutaneous/transcutaneous allergen-specific immunotherapy: rationale and clinical trials. Curr Opin Allergy Clin Immunol 2010;10:582586.

49. Lin SY, Erekosima N, Kim JM, Ramanathan M, Suarez-Cuervo C, Chelladurai Y et al. Sublingual Immunotherapy for the Treatment of Allergic Rhinoconjunctivitis and Asthma. JAMA 2013;309:1278.

50. Narisety SD, Frischmeyer-Guerrerio PA, Keet CA, Gorelik M, Schroeder J, Hamilton RG et al. A randomized, double-blind, placebo-controlled pilot study of sublingual versus oral immunotherapy for the treatment of peanut allergy. J Allergy Clin Immunol 2015;135:12751282.e6.

51. Keet CA, Frischmeyer-Guerrerio PA, Thyagarajan A, Schroeder JT, Hamilton RG, Boden S et al. The safety and efficacy of sublingual and oral immunotherapy for milk allergy. J Allergy Clin Immunol 2012;129:448-455.e5.

52. Smaldini PL, Trejo F, Cohen JL, Piaggio E, Docena GH. Systemic IL-2/anti-IL-2Ab complex combined with sublingual immunotherapy suppresses experimental food allergy in mice through induction of mucosal regulatory T cells. Allergy 2018;73:885-895.

53. Dioszeghy V, Mondoulet L, Puteaux E, Dhelft V, Ligouis M, Plaquet C et al. Differences in phenotype, homing properties and suppressive activities of regulatory T cells induced by epicutaneous, oral or sublingual immunotherapy in mice sensitized to peanut. Cell $\mathrm{Mol}$ Immunol 2017;14:770-782.

54. Zhu F-G, Kandimalla ER, Yu D, Agrawal S. Oral administration of a synthetic agonist of Toll-like receptor 9 potently modulates peanut-induced allergy in mice. J Allergy Clin Immunol 2007;120:631-637.

55. Srivastava KD, Siefert A, Fahmy TM, Caplan MJ, Li X-M, Sampson HA. Investigation of peanut oral immunotherapy with $\mathrm{CpG} /$ peanut nanoparticles in a murine model of peanut allergy. $J$

This article is protected by copyright. All rights reserved. 
Allergy Clin Immunol 2016;138:536-543.e4.

56. Kulis M, Gorentla B, Burks AW, Zhong X-P. Type B CpG oligodeoxynucleotides induce Th1 responses to peanut antigens: modulation of sensitization and utility in a truncated immunotherapy regimen in mice. Mol Nutr Food Res 2013;57:906-915.

57. San Román B, Irache JM, Gómez S, Gamazo C, Espuelas S. Co-Delivery of Ovalbumin and CpG Motifs into Microparticles Protected Sensitized Mice from Anaphylaxis. Int Arch Allergy Immunol 2009;149:111-118.

58. Li X-M, Srivastava K, Huleatt JW, Bottomly K, Burks AW, Sampson HA. Engineered recombinant peanut protein and heat-killed Listeria monocytogenes coadministration protects against peanut-induced anaphylaxis in a murine model. J Immunol 2003;170:32893295.

59. Li X-M, Srivastava K, Grishin A, Huang C-K, Schofield B, Burks W et al. Persistent protective effect of heat-killed Escherichia coli producing 'engineered,' recombinant peanut proteins in a murine model of peanut allergy. J Allergy Clin Immunol 2003;112:159-167.

60. Schiavi E, Barletta B, Butteroni C, Corinti S, Boirivant M, Di Felice G. Oral therapeutic administration of a probiotic mixture suppresses established Th2 responses and systemic anaphylaxis in a murine model of food allergy. Allergy 2011;66:499-508.

61. O'Konek JJ, Landers JJ, Janczak KW, Goel RR, Mondrusov AM, Wong PT et al. Nanoemulsion adjuvant-driven redirection of TH2 immunity inhibits allergic reactions in murine models of peanut allergy. J Allergy Clin Immunol Published Online First: 11 April 2018. doi:10.1016/j.jaci.2018.01.042

62. Smarr CB, Hsu C-L, Byrne AJ, Miller SD, Bryce PJ. Antigen-fixed leukocytes tolerize Th2 responses in mouse models of allergy. J Immunol 2011;187:5090-5098.

63. Tao Z, Li S, Ichim TE, Yang J, Riordan N, Yenugonda V et al. Cellular immunotherapy of cancer: an overview and future directions. Immunotherapy 2017;9:589-606.

This article is protected by copyright. All rights reserved. 
64. Dawicki W, Li C, Town J, Zhang X, Gordon JR. Therapeutic reversal of food allergen sensitivity by mature retinoic acid-differentiated dendritic cell induction of LAG3(+)CD49b(-)Foxp3(-) regulatory T cells. J Allergy Clin Immunol 2017;139:1608-1620.e3.

65. Ulivieri C, Baldari CT. T-cell-based immunotherapy of autoimmune diseases. Expert Rev Vaccines 2013;12:297-310.

This article is protected by copyright. All rights reserved. 
Table 1 - Therapeutic animal models in food allergy

\begin{tabular}{|c|c|c|c|c|c|c|c|c|}
\hline Route & Intervention & $\begin{array}{l}\text { Allergen } \\
\text { (sensitization) }\end{array}$ & Host & Sensitization & Treatment & Challenge & Outcomes & Ref. \\
\hline \multicolumn{9}{|c|}{ Oral Immunotherapy (OIT) } \\
\hline Oral & Egg white & $\begin{array}{l}\text { Ovalbumin } \\
\text { (Egg) }\end{array}$ & $\begin{array}{l}\text { Mouse; } \\
\mathrm{C} 3 \mathrm{H} / \mathrm{HeJ}\end{array}$ & $\begin{array}{l}\text { Oral; } 1 \mathrm{mg} \\
\text { ovalbumin }+10 \mu \mathrm{g} \\
\text { CT weekly, } 6 \text { wks }\end{array}$ & $\begin{array}{l}\text { Increasing } 1- \\
50 \mathrm{mg} / \text { day egg } \\
\text { white for } 14 \\
\text { days }\end{array}$ & $\begin{array}{l}\text { Oral; } 50 \mathrm{mg} \\
\text { ovalbumin }\end{array}$ & $\begin{array}{l}\text { Short term amelioration of } \\
\text { anaphylaxis (temperature } \\
\text { loss) and disease score } \\
\text { Clinical desensitization lost } \\
\text { 2wks post treatment } \\
\text { Increased serum ovalbumin- } \\
\text { specific IgE and IgA, and } \\
\text { similar IgG1 and IgG2a post- } \\
\text { treatment } \\
\text { Suppression of splenic T cell } \\
\text { cytokines (IL-13, IL-10 and } \\
\text { IFN- } \gamma \text { ) } 2 \text { wks post-treatment } \\
\text { Treatment induces increased } \\
\text { gut permeability }\end{array}$ & [12] \\
\hline Oral & Egg white & $\begin{array}{l}\text { Ovomucoid } \\
\text { (Egg) }\end{array}$ & $\begin{array}{l}\text { Mouse; } \\
\mathrm{C} 3 \mathrm{H} / \mathrm{HeJ}\end{array}$ & $\begin{array}{l}\text { Oral; } 1 \mathrm{mg} \\
\text { ovomucoid } \\
+10 \mu \mathrm{g} \mathrm{CT} \text { weekly, } 6 \\
\text { wks }\end{array}$ & $\begin{array}{l}\text { Increasing } 1 \text { - } \\
50 \mathrm{mg} / \text { day egg } \\
\text { white for } 14 \\
\text { days }\end{array}$ & $\begin{array}{l}\text { Oral; } 25 \mathrm{mg} \\
\text { ovomucoid }\end{array}$ & $\begin{array}{l}\text { Short term amelioration of } \\
\text { anaphylaxis (temperature } \\
\text { loss) and disease score } \\
\text { Desensitization lost after } 2 \\
\text { wks post-treatment }\end{array}$ & [12] \\
\hline Oral & $\begin{array}{l}\text { Native or heated } \\
\text { ovomucoid }\end{array}$ & $\begin{array}{l}\text { Ovomucoid } \\
\text { (Egg) }\end{array}$ & $\begin{array}{l}\text { Mouse; } \\
\mathrm{C} 3 \mathrm{H} / \mathrm{HeJ}\end{array}$ & $\begin{array}{l}\text { Oral; } 1 \mathrm{mg} \\
\text { ovomucoid + } 10 \mu \mathrm{g} \\
\text { CT weekly, } 6 \text { wks }\end{array}$ & $\begin{array}{l}\text { Increasing } 0.5 \\
-25 \mathrm{mg} / \mathrm{day} \\
\text { ovomucoid for } \\
14 \text { days }\end{array}$ & $\begin{array}{l}\text { Oral; } 25 \mathrm{mg} \\
\text { ovomucoid }\end{array}$ & $\begin{array}{l}\text { Abrogation of anaphylaxis } \\
\text { and disease score }\end{array}$ & [12] \\
\hline Oral & Ovalbumin & $\begin{array}{l}\text { Ovalbumin } \\
\text { (Egg) }\end{array}$ & $\begin{array}{l}\text { Mouse; } \\
\mathrm{C} 3 \mathrm{H} / \mathrm{HeJ}\end{array}$ & $\begin{array}{l}\text { Skin; } 100 \mu \mathrm{g} \\
\text { ovalbumin weekly, } 6 \\
\text { wks }\end{array}$ & $\begin{array}{l}1 \mathrm{mg} \\
\text { ovalbumin, } \\
\text { daily, } 8 \mathrm{wks}\end{array}$ & $\begin{array}{l}\text { Oral; } 10,20, \\
\text { and } 50 \mathrm{mg} \\
\text { ovalbumin } \\
30 \text { min apart }\end{array}$ & $\begin{array}{l}\text { Short term amelioration of } \\
\text { anaphylaxis (temperature } \\
\text { loss) } \\
\text { Desensitization lost after } 5 \\
\text { wks post-treatment } \\
\text { Increased serum IgG1 and } \\
\text { IgG2a }\end{array}$ & [13] \\
\hline Oral & Ovalbumin & $\begin{array}{l}\text { Ovalbumin } \\
\text { (Egg) }\end{array}$ & $\begin{array}{l}\text { Mouse; } \\
\mathrm{C} 3 \mathrm{H} / \mathrm{HeJ}\end{array}$ & $\begin{array}{l}\text { Oral; } 1 \mathrm{mg} \\
\text { ovalbumin }+10 \mu \mathrm{g} \\
\text { CT weekly, } 6 \text { wks }\end{array}$ & $\begin{array}{l}1 \mathrm{mg} \\
\text { ovalbumin, } \\
\text { daily, } 8 \text { wks }\end{array}$ & $\begin{array}{l}\text { Oral; } 10,20, \\
\text { and } 50 \mathrm{mg} \\
\text { ovalbumin } \\
30 \text { min apart }\end{array}$ & $\begin{array}{l}\text { No effect on anaphylaxis } \\
\text { (temperature loss) } \\
\text { No effect on serum allergen- } \\
\text { specific IgG1 and IgG2a }\end{array}$ & [13] \\
\hline Oral & Cow milk protein & $\begin{array}{l}\text { Cow milk } \\
\text { protein }\end{array}$ & $\begin{array}{l}\text { Mouse; } \\
\text { BALB/c }\end{array}$ & $\begin{array}{l}\text { Oral; } 20 \mathrm{mg} \text { cow milk } \\
\text { protein }+10 \mathrm{cT} \\
\text { weekly, } 6 \mathrm{wks}\end{array}$ & $\begin{array}{l}10 \mu \mathrm{g} \text { cow } \\
\text { milk protein } \\
\text { weekly, } 4 \text { or } 8 \\
\text { wks }\end{array}$ & $\begin{array}{l}\text { Oral; } 10 \mathrm{mg} \\
\text { cow milk } \\
\text { protein }\end{array}$ & $\begin{array}{l}\text { Clinical scores ameliorated } \\
\text { and negative skin test after } 8 \\
\text { wks of therapy } \\
\text { Decreased serum allergen- } \\
\text { specific IgE and IgG1, but } \\
\text { similar IgG2a }\end{array}$ & [14] \\
\hline
\end{tabular}

This article is protected by copyright. All rights reserved. 


\begin{tabular}{|c|c|c|c|c|c|c|c|c|}
\hline & & & & & & & $\begin{array}{l}\text { Suppression of splenic } \\
\text { allergen-specific cytokines IL- } \\
5 \text { and IL-13, but unchanged } \\
\text { IFN- } \gamma \\
\text { Reduced intestinal } \\
\text { expression of IL-5, IL-13 and } \\
\text { GATA3, and increased IFN- } \gamma \text {, } \\
\text { IL-10, TGF- } \beta \text { and FoxP3 } \\
\text { Elevated percentages of } \\
\text { intestinal CD4 }{ }^{+} \text {CD25 } 25^{+} \text {FoxP3 }^{+} \\
\text {cells expressing IL-10 }\end{array}$ & \\
\hline Oral & Whey & Whey (milk) & $\begin{array}{l}\text { Mouse; } \\
\mathrm{C} 3 \mathrm{H} / \mathrm{HeOuJ}\end{array}$ & $\begin{array}{l}\text { IG; } 20 \text { mg whey + } 20 \\
\mu \mathrm{g} C T ; \text { day } 0,7,14 \text {, } \\
21 \\
\text { and } 28\end{array}$ & $\begin{array}{l}0.1,1,10 \text { or } \\
100 \text { mg whey } \\
5 x \text { weekly for } \\
3 \text { wks }\end{array}$ & $\begin{array}{l}50 \mathrm{mg} \text { IG, } \\
100 \mathrm{mg} \text { IP, } \\
\text { or } 10 \mu \mathrm{g} \mathrm{ID} \text {; } \\
\text { whey }\end{array}$ & $\begin{array}{l}\text { Decreased ear swelling, } \\
\text { anaphylaxis score and } \\
\text { temperature loss following ID } \\
\text { challenge } \\
\text { Decreased serum mMCP-1 } \\
\text { levels following IG challenge } \\
\text { No protection from IP- } \\
\text { induced anaphylaxis } \\
\text { Similar allergen-specific IgE, } \\
\text { and increased IgG1 and IgG2a } \\
\text { level in serum } \\
\text { Reduced CD4 }{ }^{+} \mathrm{CD} 69^{+} \mathrm{ST2} 2^{+} \mathrm{Th} 2 \\
\text { cells and increased } \\
\mathrm{CD} 4^{+} \mathrm{CD} 69^{+} \mathrm{CXCR3^{+ }} \text { Th1 cells } \\
\text { in spleen } \\
\mathrm{CD} 4^{+} \mathrm{CD} 25^{+} \text {FoxP3 }{ }^{+} \text {regulatory } \\
\mathrm{T} \text { cells increased in mLN, but } \\
\text { not spleen } \\
\text { Suppressed allergen-specific } \\
\text { IL-5 and IL-13, and similar IL- } \\
10 \text { and IFN- }-\gamma \text { production by } \\
\text { splenocytes }\end{array}$ & [15] \\
\hline Oral & $\begin{array}{l}\text { Peanut butter; Anti- } \\
\text { IgE or SYKi facilitated }\end{array}$ & Peanut butter & $\begin{array}{l}\text { Mouse; } \\
\text { allergy- } \\
\text { prone } \\
\text { ॥4raF709 }\end{array}$ & $\begin{array}{l}\text { Oral; } 23 \mathrm{mg} \text { peanut } \\
\text { butter ( } 5 \mathrm{mg} \\
\text { protein) weekly, } 4 \\
\text { wks }\end{array}$ & $\begin{array}{l}225 \mathrm{mg} \\
\text { peanut butter } \\
\text { daily, } 3 \text { wks; } \\
25 \mu \mathrm{kg} / \mathrm{day} \\
\text { anti-IgE IP for } \\
4 \text { days before } \\
\text { peanut or } 30 \\
\mathrm{mg} / \mathrm{kg} \text { SYKi IG } \\
\text { daily with the } \\
\text { peanut }\end{array}$ & $\begin{array}{l}\text { Oral; } 430 \mathrm{mg} \\
\text { peanut } \\
\text { butter }\end{array}$ & $\begin{array}{l}\text { Prolonged suppression of } \\
\text { anaphylaxis } \\
\text { Expansion of allergen-specific } \\
\text { regulatory T cells } \\
\text { Suppression of allergen- } \\
\text { specific Th2 immune } \\
\text { responses }\end{array}$ & [17] \\
\hline Oral & $\begin{array}{l}\text { Peanut protein } \\
\text { extract }\end{array}$ & $\begin{array}{l}\text { Peanut } \\
\text { protein }\end{array}$ & $\begin{array}{l}\text { Mouse; } \\
\mathrm{C} 3 \mathrm{H} / \mathrm{HeOuJ}\end{array}$ & $\begin{array}{l}\text { IG; } 6 \mathrm{mg} \text { peanut } \\
\text { protein extract }+20\end{array}$ & $\begin{array}{l}0.15,1.5, \text { or } \\
15 \mathrm{mg} \text { peanut }\end{array}$ & $\begin{array}{l}15 \mathrm{mg} \text { IG, } \\
100 \mathrm{mg} \text { IP, }\end{array}$ & $\begin{array}{l}\text { Decreased ear swelling } \\
\text { following ID challenge }\end{array}$ & [15] \\
\hline
\end{tabular}

This article is protected by copyright. All rights reserved. 


\begin{tabular}{|c|c|c|c|c|c|c|c|c|}
\hline & & extract & & $\begin{array}{l}\mu \mathrm{g} \mathrm{CT} ; \text { day } 0,1,2,7, \\
14,21 \text { and } 28\end{array}$ & $\begin{array}{l}\text { protein } \\
\text { extract } 5 x \\
\text { weekly for } 3 \\
\text { wks }\end{array}$ & $\begin{array}{l}\text { or } 1 \mu \mathrm{g} I \mathrm{D} ; \\
\text { peanut } \\
\text { protein } \\
\text { extract }\end{array}$ & 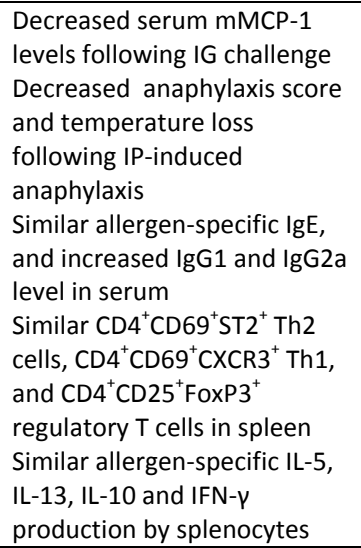 & \\
\hline Oral & $\begin{array}{l}\text { Peanut protein } \\
\text { extract }\end{array}$ & $\begin{array}{l}\text { Peanut } \\
\text { protein } \\
\text { extract }\end{array}$ & $\begin{array}{l}\text { Mouse; } \\
\text { BALB/c }\end{array}$ & $\begin{array}{l}\text { IG; } 1 \text { mg peanut } \\
\text { protein extract }+10 \\
\mu \mathrm{g} \text { CT weekly for } 6 \\
\text { wks }\end{array}$ & $\begin{array}{l}1 \mathrm{mg} \text { peanut } \\
\text { protein } \\
\text { extract week } \\
1,2 \mathrm{mg} \\
\text { protein week } \\
2 \text {, and } 5 \mathrm{mg} \\
\text { protein week } \\
3-8 \text {. }\end{array}$ & None & $\begin{array}{l}\text { Suppression of allergen- } \\
\text { specific IgE and induction of } \\
\text { IgG2a } \\
\text { Reduced ex vivo splenic } \\
\text { allergen-specific IL-5 and IL- } \\
13 \text {, and increased IL-10 } \\
\text { Increased splenic CD4 } \\
\text { regulatory T cells expressing } \\
\text { FoxP3, CTLA-4, LAP, CCR9 and } \\
\text { CCR4 }\end{array}$ & [16] \\
\hline \multicolumn{9}{|c|}{ Intraperitoneal immunotherapy (IPIT) } \\
\hline IP & $\begin{array}{l}\text { Cashew protein } \\
\text { extract }\end{array}$ & $\begin{array}{l}\text { Cashew } \\
\text { protein } \\
\text { extract }\end{array}$ & $\begin{array}{l}\text { Mouse; } \\
\text { C3H/HeJ }\end{array}$ & $\begin{array}{l}\text { Oral; } 2 \text { mg cashew } \\
\text { protein extract }+10 \\
\mu \mathrm{g} \mathrm{CT} \text { day } 1,8 \text { and } \\
15 \text {, and } 5 \mathrm{mg} \text { protein } \\
+10 \mu \mathrm{g} \text { CT day } 22\end{array}$ & $\begin{array}{l}3 \text { IP doses } \\
\text { weekly; } \\
\text { Dosing: } 50 \mu \mathrm{g} \\
\text { cashew } \\
\text { protein } \\
\text { extract week } \\
1,125 \mu \mathrm{g} \\
\text { week 2, and } \\
200 \mu \mathrm{g} \text { week } \\
3+4 \\
\end{array}$ & $\begin{array}{l}\text { IP; } 1 \mathrm{mg} \\
\text { cashew } \\
\text { protein } \\
\text { extract } 14 \\
\text { days post } \\
\text { treatment }\end{array}$ & $\begin{array}{l}\text { Abrogation of anaphylaxis } \\
\text { (temperature loss) and } \\
\text { disease score } \\
\text { Increased allergen-specific } \\
\text { IgG1 and IgG2a, but no effect } \\
\text { on IgE } \\
\text { Suppression of splenic } \\
\text { allergen-specific cytokines IL- } \\
5 \text { and IL-13, but unchanged } \\
\text { IL-4 and IFN- }-\end{array}$ & [21] \\
\hline IP & $\begin{array}{l}\text { Cashew protein } \\
\text { extract in cross- } \\
\text { reactivity model }\end{array}$ & $\begin{array}{l}\text { Cashew or } \\
\text { egg protein } \\
\text { extract }\end{array}$ & $\begin{array}{l}\text { Mouse; } \\
\text { C3H/HeJ }\end{array}$ & $\begin{array}{l}\text { IP; } 500 \mu g \text { protein } \\
\text { extract (cashew or } \\
\text { egg) }+2 \text { mg alum } \\
\text { week } 1,2 \text { and } 4\end{array}$ & $\begin{array}{l}\text { I IP doses } \\
\text { weekly; } \\
\text { Dosaging: } 100 \\
\mu \mathrm{g} \text { protein } \\
\text { extract } \\
\text { (cashew) week } \\
1,250 \mu \mathrm{g}\end{array}$ & $\begin{array}{l}\text { IP; } 1 \mathrm{mg} \\
\text { protein } \\
\text { extract } \\
\text { (cashew, } \\
\text { pistachio, or } \\
\text { egg) }\end{array}$ & $\begin{array}{l}\text { Abrogation of anaphylaxis } \\
\text { (temperature loss) and } \\
\text { disease score following } \\
\text { cashew or pistachio } \\
\text { challenge in cashew- } \\
\text { sensitized mice } \\
\text { Increased allergen-specific }\end{array}$ & [22] \\
\hline
\end{tabular}

This article is protected by copyright. All rights reserved. 


\begin{tabular}{|c|c|c|c|c|c|c|c|c|}
\hline & & & & & & & $\begin{array}{l}\text { mice receiving therapy with } \\
\text { intact cashew protein }\end{array}$ & \\
\hline Oral & $\begin{array}{l}\text { Hydrolyzed egg } \\
\text { white proteins }\end{array}$ & $\begin{array}{l}\text { Egg white } \\
\text { proteins }\end{array}$ & $\begin{array}{l}\text { Mouse; } \\
\text { BALB/c }\end{array}$ & $\begin{array}{l}\text { Oral; } 5 \mathrm{mg} \text { egg white } \\
\text { proteins + } 10 \mu \mathrm{g} \mathrm{CT} \\
2 \mathrm{x} \text { weekly, } 4 \text { wks }\end{array}$ & $\begin{array}{l}\text { Oral; } 5 \mathrm{mg} \\
\text { hydrolyzed } \\
\text { egg white } \\
\text { proteins } 3 x \\
\text { weekly, } 3 \text { wks }\end{array}$ & $\begin{array}{l}\text { Oral; } 20 \mathrm{mg} \\
\text { egg white } \\
\text { proteins }\end{array}$ & $\begin{array}{l}\text { Normalization of serum } \\
\text { histamine } \\
\text { Decreased allergen-specific } \\
\text { IgE and IgG2a, and } \\
\text { unchanged IgG and IgG1 } \\
\text { Reduced allergen-specific IL-4 } \\
\text { and IFN- } \gamma \text { by splenocytes } \\
\text { Reduced intestinal } \\
\text { expression of IL-4, IL-13, IFN- } \\
\gamma \text {, IL-10 and IL-12p40, and } \\
\text { increased IL-18, IL-5, TGF- } \beta \\
\text { and FoxP3 }\end{array}$ & [23] \\
\hline \multicolumn{9}{|c|}{$T$ cell directed peptide immunotherapy } \\
\hline Oral & $\begin{array}{l}\text { Peptides from } \\
\text { ovalbumin } \\
\text { (immunodominat } \mathrm{T} \\
\text { cell epitopes) - } 3 \\
\text { single peptides or } \\
\text { cocktail }\end{array}$ & $\begin{array}{l}\text { Ovalbumin } \\
\text { (Egg) }\end{array}$ & $\begin{array}{l}\text { Mouse; } \\
\text { BALB/c }\end{array}$ & $\begin{array}{l}\text { Oral; } 1 \mathrm{mg} \\
\text { ovalbumin }+10 \mu \mathrm{g} \\
\text { CT } 2 x \text { weekly, } 4 \text { wks }\end{array}$ & $\begin{array}{l}\text { Oral; } 100 \mu \mathrm{g} \\
\text { peptide } 3 \mathrm{x} \\
\text { weekly, } 3 \text { wks }\end{array}$ & $\begin{array}{l}\text { Oral; } 20 \mathrm{mg} \\
\text { ovalbumin }\end{array}$ & $\begin{array}{l}\text { Peptide cocktail suppressed } \\
\text { anaphylactic disease scores } \\
\text { and serum histamine levels } \\
\text { Reduced allergen-specific IgE } \\
\text { and unchanged IgG } \\
\text { Allergen-specific decreased } \\
\text { IL-4 and increased IFN- } \gamma \text { in } \\
\text { splenocytes } \\
\text { Reduced intestinal } \\
\text { expression of IL-4, IL-5, IL-13, } \\
\text { and increased TGF- } \beta \text { and } \\
\text { FoxP3 } \\
\text { Possibly increased fecal IgA }\end{array}$ & [34] \\
\hline Oral & $\begin{array}{l}\text { Peptide from } \\
\text { ovomucoid } \\
\text { (immunodominat T } \\
\text { cell epitope) - single } \\
\text { or triple sequence }\end{array}$ & $\begin{array}{l}\text { Ovomucoid } \\
\text { (Egg) }\end{array}$ & $\begin{array}{l}\text { Mouse; } \\
\text { BALB/c }\end{array}$ & $\begin{array}{l}\text { Oral; } 1 \mathrm{mg} \\
\text { ovomucoid + } 10 \mu \mathrm{g} \\
\text { CT 2x weekly, } 4 \text { wks }\end{array}$ & $\begin{array}{l}\text { Oral; } 1 \mathrm{mg} \\
\text { single or } 3 \mathrm{mg} \\
\text { triple } 3 \mathrm{x} \\
\text { weekly, } 4 \text { wks }\end{array}$ & $\begin{array}{l}\text { Oral; } 20 \mathrm{mg} \\
\text { ovomucoid }\end{array}$ & $\begin{array}{l}\text { Peptide abrogated disease } \\
\text { score and histamine release } \\
\text { Decreased allergen-specific } \\
\text { IgE, similar IgG, IgG1 and } \\
\text { increased IgG2a } \\
\text { Possibly increased fecal IgA } \\
\text { Allergen-specific decreased } \\
\text { IL-4 and increased IL-12, IFN- } \\
\text { pand IL-10 in splenocytes } \\
\text { Increase percentage of blood } \\
\mathrm{CD4}^{+} \text {FoxP3 }^{+} \text {cells }\end{array}$ & [35] \\
\hline Oral & $\begin{array}{l}\text { Peptides from } \\
\text { shrimp-tropomyosin } \\
\text { (immunodominat T } \\
\text { cell epitopes) - } \\
\text { Cocktail of } 6 \\
\end{array}$ & $\begin{array}{l}\text { Recombinant } \\
\text { shrimp- } \\
\text { tropomyosin }\end{array}$ & $\begin{array}{l}\text { Mouse; } \\
\text { BALB/c }\end{array}$ & $\begin{array}{l}\text { Oral; } 100 \mu \mathrm{g} \\
\text { recombinant shrimp- } \\
\text { tropomyosin }+10 \mu \mathrm{g} \\
\mathrm{CT} \text { day } 0,12,19 \text {, and } \\
26\end{array}$ & $\begin{array}{l}\text { Oral; } 1,2 \mathrm{mg} \\
\text { peptide mix } 2 \mathrm{x} \\
\text { weekly, } 4 \text { wks }\end{array}$ & $\begin{array}{l}\text { Oral; } 500 \mu g \\
\text { recombinant } \\
\text { shrimp- } \\
\text { tropomyosin }\end{array}$ & $\begin{array}{l}\text { Peptide cocktail suppressed } \\
\text { disease scores, diarrhea, and } \\
\text { serum mMCP-1 levels } \\
\text { Decreased allergen-specific } \\
\text { IgE, increased IgG2a and }\end{array}$ & [28] \\
\hline
\end{tabular}

This article is protected by copyright. All rights reserved. 


\begin{tabular}{|c|c|c|c|c|c|c|c|c|}
\hline & peptides & & & & & & $\begin{array}{l}\text { similar IgG1 in serum } \\
\text { Suppression of intestinal IL-5 } \\
\text { and IL-13 expression, and } \\
\text { increased FoxP3, CD25, IL-10, } \\
\text { IL-12, IL-18 and IFN- } \gamma \\
\text { Allergen-specific decreased } \\
\text { IL-4 and IL-5, and increased } \\
\text { IFN- } \gamma \text { in splenocytes }\end{array}$ & \\
\hline Oral & $\begin{array}{l}\text { Peptides from beta- } \\
\text { lactoglobulin } \\
\text { (immunodominat } \mathrm{T} \\
\text { cell epitopes) - } 2 \\
\text { single peptides }\end{array}$ & $\begin{array}{l}\text { beta- } \\
\text { lactoglobulin } \\
\text { (Milk) }\end{array}$ & $\begin{array}{l}\text { Mouse; } \\
\text { BALB/c }\end{array}$ & $\begin{array}{l}\text { IP; } 50 \mu \mathrm{\mu g} \text { beta- } \\
\text { lactoglobulin }+2 \mathrm{mg} \\
\text { alum weekly, } 3 \text { wks }\end{array}$ & $\begin{array}{l}\text { Oral; } 1 \mathrm{mg} \\
\text { peptide } 3 \mathrm{x} \\
\text { weekly, } 4 \text { wks }\end{array}$ & $\begin{array}{l}\text { Oral; } 50 \mathrm{mg} \\
\text { beta- } \\
\text { lactoglobulin }\end{array}$ & $\begin{array}{l}\text { Peptides abrogation of } \\
\text { anaphylaxis (temperature } \\
\text { loss) and suppressed disease } \\
\text { scores } \\
\text { No effect on serum allergen- } \\
\text { specific IgE, IgG1, IgG2a, IgA, } \\
\text { total-IgE, or fecal total-IgA } \\
\text { No differences in allergen- } \\
\text { specific IFN- }- \text {, IL-12, IL-4 } \\
\text { and/IL-10 in splenocytes or } \\
\mathrm{mLN} \text { cells } \\
\text { No difference in splenic } \\
\mathrm{CD} 4^{+} \mathrm{CD} 25^{+} \text {FoxP3 }{ }^{+} \text {regulatory } \\
\mathrm{T} \text { cell population }\end{array}$ & [36] \\
\hline \multicolumn{9}{|c|}{ Subcutaneous immunotherapy (SCIT) } \\
\hline SC & Whey & Whey (milk) & $\begin{array}{l}\text { Mouse; } \\
\mathrm{C} 3 \mathrm{H} / \mathrm{HeOuJ}\end{array}$ & $\begin{array}{l}\text { IG; } 20 \mathrm{mg} \text { whey }+20 \\
\mu \mathrm{g} \mathrm{CT} ; \text { day } 0,7,14, \\
21, \\
\text { and } 28\end{array}$ & $\begin{array}{l}\text { SC; } 2.5,10 \text { or } \\
25 \mu \mathrm{g} \text { whey } 3 \mathrm{x} \\
\text { weekly, } 3 \text { wks }\end{array}$ & $\begin{array}{l}50 \mathrm{mg} \text { IG, } \\
100 \mathrm{mg} \text { IP, } \\
\text { or } 10 \mu \mathrm{gg} \text { ID; } \\
\text { whey }\end{array}$ & 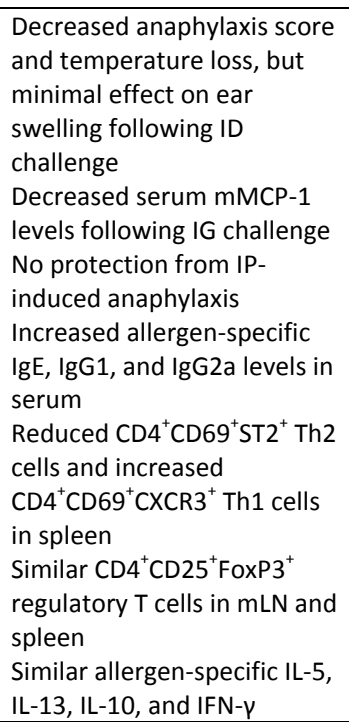 & [15] \\
\hline
\end{tabular}

This article is protected by copyright. All rights reserved. 


\begin{tabular}{|c|c|c|c|c|c|c|c|c|}
\hline & & & & & & & production by splenocytes & \\
\hline SC & $\begin{array}{l}\text { Peanut protein } \\
\text { extract }\end{array}$ & $\begin{array}{l}\text { Peanut } \\
\text { protein } \\
\text { extract }\end{array}$ & $\begin{array}{l}\text { Mouse; } \\
\text { C3H/HeOuJ }\end{array}$ & $\begin{array}{l}\text { IG.; } 6 \text { mg peanut } \\
\text { protein extract }+20 \\
\mu \mathrm{C} \mathrm{CT} ; \text { day } 0,1,2,7 \text {, } \\
14,21 \text {, and } 28\end{array}$ & $\begin{array}{l}\text { SC; } 1,10 \text { or } \\
100 \mu g \text { peanut } \\
\text { protein } \\
\text { extract } 3 \mathrm{x} \\
\text { weekly, } 3 \text { wks }\end{array}$ & $\begin{array}{l}15 \mathrm{mg} \text { IG, } \\
100 \mathrm{mg} \text { IP, } \\
\text { or } 1 \mu \mathrm{g} \mathrm{ID} ; \\
\text { peanut } \\
\text { protein } \\
\text { extract }\end{array}$ & 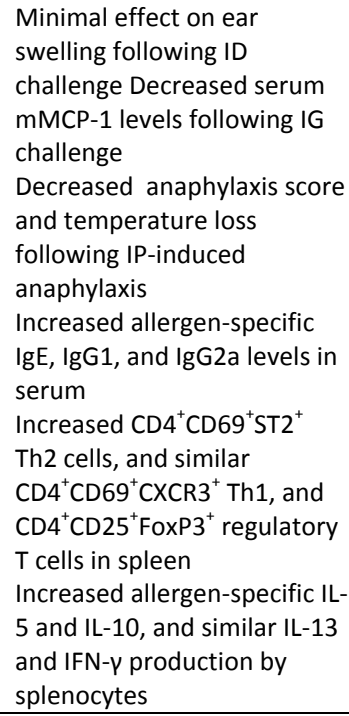 & [15] \\
\hline \multicolumn{9}{|c|}{ Epicutaneous immunotherapy (EPIT) } \\
\hline EP & Ovalbumin & $\begin{array}{l}\text { Ovalbumin } \\
\text { (Egg) }\end{array}$ & $\begin{array}{l}\text { Mouse; } \\
\text { C3H/HeJ }\end{array}$ & $\begin{array}{l}\text { Skin; } 100 \mu \mathrm{g} \\
\text { ovalbumin weekly, } 6 \\
\text { wks }\end{array}$ & $\begin{array}{l}100 \mu \mathrm{g} \\
\text { ovalbumin in } \\
\text { Viaskin patch } \\
48 \text { hours } \\
\text { weekly, } 8 \text { wks }\end{array}$ & $\begin{array}{l}\text { Oral; } 10,20, \\
\text { and } 50 \mathrm{mg} \\
\text { ovalbumin } \\
30 \text { min apart }\end{array}$ & $\begin{array}{l}\text { Long-term reversal of } \\
\text { anaphylaxis (temperature } \\
\text { loss) at } 1 \text { and } 5 \text { weeks post- } \\
\text { treatment } \\
\text { Persistent increased serum } \\
\text { allergen-specific IgG1 and } \\
\text { IgG2a at } 1 \text { and } 5 \text { weeks post- } \\
\text { treatment } \\
\text { No effect in basophil } \\
\text { activation tests } \\
\text { No therapeutic blocking } \\
\text { antibodies demonstrated by } \\
\text { passive sensitization of naïve } \\
\text { animal } \\
\text { Therapeutic induction of } \\
\text { CD4 }{ }^{+} \text {LAP }{ }^{+} \text {FoxP3 } 3^{-} \text {regulatory } T \\
\text { cells in skin dLN and } \mathrm{mLN} \\
\text { expressing CCR9, CCR6 and } \\
\text { CCR4 } \\
\text { Therapeutic effect mediate } \\
\text { by TGF- } \beta\end{array}$ & [13] \\
\hline
\end{tabular}

This article is protected by copyright. All rights reserved. 


\begin{tabular}{|c|c|c|c|c|c|c|c|c|}
\hline EP & Ovalbumin & $\begin{array}{l}\text { Ovalbumin } \\
\text { (Egg) }\end{array}$ & $\begin{array}{l}\text { Mouse; } \\
\mathrm{C} 3 \mathrm{H} / \mathrm{HeJ}\end{array}$ & $\begin{array}{l}\text { Oral; } 1 \mathrm{mg} \\
\text { ovalbumin + } 10 \mu \mathrm{g} \\
\text { CT weekly, } 6 \text { wks }\end{array}$ & $\begin{array}{l}100 \mu \mathrm{g} \\
\text { ovalbumin in } \\
\text { Viaskin patch } \\
48 \text { hours } \\
\text { weekly, } 8 \text { wks }\end{array}$ & $\begin{array}{l}\text { Oral; } 10,20, \\
\text { and } 50 \mathrm{mg} \\
\text { ovalbumin } \\
30 \mathrm{~min} \text { apart }\end{array}$ & $\begin{array}{l}\text { Reversal of anaphylaxis } \\
\text { (temperature loss) } \\
\text { Increased allergen-specific } \\
\text { IgG1 and IgG2a at } 1 \text { week, } \\
\text { but not } 5 \text { weeks post } \\
\text { treatment } \\
\text { No effect in basophil } \\
\text { activation tests } \\
\text { No therapeutic blocking } \\
\text { antibodies demonstrated by } \\
\text { passive sensitization of naïve } \\
\text { animal } \\
\text { Therapeutic induction of } \\
\text { CD4 } 4^{+} \text {LAP }{ }^{+} \text {FoxP3 regulatory T } \\
\text { cells in skin bLN and mLN } \\
\text { expressing CCR9, CCR6 and } \\
\text { CCR4 } \\
\text { Therapeutic effect mediate } \\
\text { by TGF- } \beta\end{array}$ & [13] \\
\hline EP & $\begin{array}{l}\text { Peanut protein } \\
\text { extract }\end{array}$ & $\begin{array}{l}\text { Peanut } \\
\text { protein } \\
\text { extract }\end{array}$ & $\begin{array}{l}\text { Mouse; } \\
\text { BALB/c }\end{array}$ & $\begin{array}{l}\text { Oral; } 1 \text { mg peanut } \\
\text { protein extract }+10 \\
\mu \mathrm{g} \text { CT weekly, } 6 \text { wks }\end{array}$ & $\begin{array}{l}100 \mu g \text { peanut } \\
\text { protein } \\
\text { extract in } \\
\text { Viaskin patch } \\
48 \text { hours } \\
\text { weekly, } 8 \text { wks }\end{array}$ & $\begin{array}{l}\text { Peanut as } \\
\text { feed day } 1- \\
4 \text {, peanut in } \\
\text { feed day } 5- \\
10 \text {, and } 10 \\
\mathrm{mg} \text { IG daily } \\
\text { the last } 3 \\
\text { days }\end{array}$ & $\begin{array}{l}\text { Suppression of esophageal } \\
\text { eosinophilia, and acanthosis } \\
\text { and inflammation scores } \\
\text { Reversal of allergic } \\
\text { enteropathy and villous } \\
\text { morphology } \\
\text { Increased IgG2a in serum } \\
\text { Reduced allergen-specific IL- } \\
5, \text { IL-13 and IL-10, and similar } \\
\text { IFN- } y \text { production by } \\
\text { splenocytes } \\
\text { FoxP3 mRNA expression in } \\
\text { esophagus } \\
\text { Increased splenic } \\
\text { CD4 } 4^{+} \text {CD25 } 25^{+} \text {FoxP3 }{ }^{+} \text {regulatory } \\
\text { T cells expressing CTLA-4, but } \\
\text { not IL-10 and PD-1 } \\
\text { Reduced eotaxin and } \\
\text { increased FoxP3 expression } \\
\text { in esophagus } \\
\text { Efficacy dependent on CD25 } \\
\text { during treatment } \\
\text { Long-term stability of } \\
\text { treatment induced regulatory } \\
\text { T cells was demonstrated by } \\
\text { adoptive transfer of } \\
\text { CD4 }{ }^{+} \text {CD25 } 5^{+} T \text { cells } 8 \text { wks post }\end{array}$ & {$[45,46]$} \\
\hline
\end{tabular}

This article is protected by copyright. All rights reserved. 


\begin{tabular}{|c|c|c|c|c|c|c|c|c|}
\hline & & & & & & & treatment & \\
\hline EP & $\begin{array}{l}\text { Peanut protein } \\
\text { extract }\end{array}$ & $\begin{array}{l}\text { Peanut } \\
\text { protein } \\
\text { extract }\end{array}$ & $\begin{array}{l}\text { Pig; (LW } x \\
\text { LR) } \times P\end{array}$ & $\begin{array}{l}\text { IP; } 100 \mu \mathrm{g} \text { peanut } \\
\text { protein extract }+8 \\
\text { mg alum week } 1,2 \text {, } \\
\text { and } 4\end{array}$ & $\begin{array}{l}100 \mu g \text { peanut } \\
\text { protein } \\
\text { extract in } \\
\text { Viaskin patch } \\
\text { for } 24 \text { hours } \\
\text { daily, } 81 \text { days }\end{array}$ & $\begin{array}{l}\text { Oral; } 4 \mathrm{mg} \\
\text { peanut } \\
\text { protein } \\
\text { extract daily } \\
\text { for } 10 \text { days }\end{array}$ & $\begin{array}{l}\text { Reversal of visual gastritis, } \\
\text { and gastric tissue } \\
\text { inflammation and } \\
\text { eosinophilia } \\
\text { Reduced serum allergen- } \\
\text { specific IgE } \\
\text { Suppression of splenic Gata3, } \\
\text { FoxP3, IL-5 and eotaxin } \\
\text { mRNA expression }\end{array}$ & {$[47]$} \\
\hline \multicolumn{9}{|c|}{ Sublingual immunotherapy (SLIT) } \\
\hline $\mathrm{SL}$ & Cow milk protein & $\begin{array}{l}\text { Cow milk } \\
\text { protein }\end{array}$ & $\begin{array}{l}\text { Mouse; } \\
\text { BALB/c }\end{array}$ & $\begin{array}{l}\text { IG; } 20 \mathrm{mg} \text { cow milk } \\
\text { protein }+10 \mu \mathrm{gg} \\
\text { weekly, } 6 \mathrm{wks}\end{array}$ & $\begin{array}{l}10 \mathrm{pg} 2 \mathrm{x} \\
\text { weekly, } 4 \\
\text { weeks. } \\
\text { Followed by } \\
10 \mathrm{ng} 2 \mathrm{x} \\
\text { weekly, } 4 \\
\text { weeks; cow } \\
\text { milk protein }\end{array}$ & $\begin{array}{l}\text { IG; } 10 \mathrm{mg} \\
\text { cow milk } \\
\text { protein } \\
\text { twice } 24 \mathrm{~h} \\
\text { apart }\end{array}$ & $\begin{array}{l}\text { Suppression of clinical } \\
\text { symptom scores } \\
\text { Decreased allergen-specific } \\
\text { serum IgE } \\
\text { Decreased allergen-specific } \\
\text { IL-5 production by } \\
\text { splenocytes } \\
\text { Increased IL-10 and TGF- } \beta \\
\text { levels in jejunum } \\
\end{array}$ & {$[52]$} \\
\hline \multicolumn{9}{|c|}{ Immunotherapy using immunomodulatory adjuvants } \\
\hline Oral & $\begin{array}{l}\text { TLR9 agonist (IMO) + } \\
\text { peanut protein } \\
\text { extract }\end{array}$ & $\begin{array}{l}\text { Peanut } \\
\text { protein } \\
\text { extract }\end{array}$ & $\begin{array}{l}\text { Mouse; } \\
\text { C3H/HeJ }\end{array}$ & $\begin{array}{l}\text { Oral; } 1 \mathrm{mg} \text { peanut } \\
\text { protein extract }+10 \\
\mu \mathrm{g} C \mathrm{CT} \text { day } 0 \text { and } 14 \text {. }\end{array}$ & $\begin{array}{l}1 \text { mg peanut } \\
\text { protein } \\
\text { extract with or } \\
\text { without } 150 \\
\mu \mathrm{g} \text { TLR9 } \\
\text { agonist day } \\
21,24,28 \text {, and } \\
31\end{array}$ & $\begin{array}{l}\mathrm{IG} ; 1 \mathrm{mg} \\
\text { peanut } \\
\text { protein } \\
\text { extract 2x, } \\
30-40 \mathrm{~min} \\
\text { interval }\end{array}$ & $\begin{array}{l}\text { Suppression of anaphylaxis } \\
\text { scores and reversal of serum } \\
\text { histamine levels } \\
\text { Reduced mast cells and } \\
\text { eosinophils in small intestine } \\
\text { Decreased in allergen-specific } \\
\text { IgE and IgG1, and increased } \\
\text { IgG2a in serum } \\
\text { Increased allergen-specific } \\
\text { IgA in intestine } \\
\text { Suppressed allergen-specific } \\
\text { IL-5 and IL-13, and increased } \\
\text { IFN- }- \text { production by } \\
\text { splenocytes }\end{array}$ & {$[54]$} \\
\hline IG & $\begin{array}{l}\text { TLR9 agonist (class B } \\
\text { CpG-ODN 1826) + } \\
\text { defatted whole } \\
\text { roasted peanut in } \\
\text { PLGA nanoparticles }\end{array}$ & $\begin{array}{l}\text { Whole } \\
\text { roasted } \\
\text { peanut }\end{array}$ & $\begin{array}{l}\text { Mouse; } \\
\text { C3H/HeJ }\end{array}$ & $\begin{array}{l}\text { IG; } 10 \mathrm{mg} \text { whole } \\
\text { roasted peanut }+20 \\
\mu \mathrm{C} C \mathrm{CT}+1.1 \mu \mathrm{\mu l} 80- \\
\text { proof EtOH pr. } \mathrm{g} \mathrm{BW} \\
\text { weekly, } 6 \text { wks. } 50 \\
\text { mg boost with same } \\
\text { adjuvant wks } 7 \text { and } 8\end{array}$ & $\begin{array}{l}200 \mu \mathrm{g} \text { whole } \\
\text { roasted } \\
\text { peanut with or } \\
\text { without } 1.8 \mu \mathrm{g} \\
\text { TLR9 agonist } \\
\text { weekly, } 4 \text { wks }\end{array}$ & $\begin{array}{l}\text { Oral; } 200 \mathrm{mg} \\
\text { whole } \\
\text { roasted } \\
\text { peanut } \\
\text { (done } \\
\text { weekly with } \\
\text { IG } \\
\text { sensitization }\end{array}$ & $\begin{array}{l}\text { Suppression of anaphylaxis } \\
\text { scores, temperature loss and } \\
\text { plasma histamine levels } \\
\text { Decrease in allergen-specific } \\
\text { IgE and IgG1, and increased } \\
\text { IgG2a in serum } \\
\text { Decreased allergen-specific } \\
\text { IL-4, IL-5 and IL-13, and }\end{array}$ & [55] \\
\hline
\end{tabular}

This article is protected by copyright. All rights reserved. 


\begin{tabular}{|c|c|c|c|c|c|c|c|c|}
\hline & & & & & & $\begin{array}{l}\text { dose the day } \\
\text { after for } 5 \\
\text { wks) }\end{array}$ & $\begin{array}{l}\text { increased IFN- } \gamma \text { production } \\
\text { by splenocytes }\end{array}$ & \\
\hline IP & $\begin{array}{l}\text { TLR9 agonist (class A } \\
\text { CpG-ODN 1585, class } \\
\text { B CpG-ODN 1826, or } \\
\text { class C CpG-ODN } \\
\text { M362) + peanut } \\
\text { protein extract }\end{array}$ & $\begin{array}{l}\text { Peanut } \\
\text { protein } \\
\text { extract }\end{array}$ & $\begin{array}{l}\text { Mouse; } \\
\text { C3H/HeJ }\end{array}$ & $\begin{array}{l}\text { IP; } 500 \mu \text { g peanut } \\
\text { protein extract }+2 \\
\text { mg alum weekly, } 3 \\
\text { wks }\end{array}$ & $\begin{array}{l}\text { Increasing } 100 \\
-500 \mu \mathrm{g} \\
\text { peanut } \\
\text { protein } \\
\text { extract with or } \\
\text { without } 30 \mu \mathrm{g} \\
\text { TLR9 agonist } \\
\text { twice weekly, } \\
3 \text { wks }\end{array}$ & $\begin{array}{l}\text { IP; } 1 \mathrm{mg} \\
\text { peanut } \\
\text { protein } \\
\text { extract }\end{array}$ & $\begin{array}{l}\text { Class B and C CpG-ODNs } \\
\text { decreased anaphylaxis } \\
\text { scores, temperature loss and } \\
\text { serum MMCP-1 levels } \\
\text { Similar allergen-specific IgE } \\
\text { and IgG1, and increased } \\
\text { IgG2a in serum } \\
\text { Decreased allergen-specific } \\
\text { IL-5 and IL-13, and similar IL- } \\
4 \text { production by splenocytes } \\
\text { Class B CpG-ODN increased } \\
\text { allergen-specific IFN- } \gamma \\
\text { production by splenocytes }\end{array}$ & [56] \\
\hline ID & $\begin{array}{l}\text { TLR9 agonist (class B } \\
\text { CpG-ODN 1826) + } \\
\text { ovalbumin in PLGA } \\
\text { nanoparticles }\end{array}$ & $\begin{array}{l}\text { Ovalbumin } \\
\text { (Egg) }\end{array}$ & $\begin{array}{l}\text { Mouse; } \\
\text { BALB/c }\end{array}$ & $\begin{array}{l}\text { IP; } 50 \mu \mathrm{g} \text { ovalbumin } \\
+2 \mathrm{mg} \text { alum weekly, } \\
2 \text { wks }\end{array}$ & $\begin{array}{l}20 \mu g \\
\text { ovalbumin } \\
\text { with or } \\
\text { without } 25 \mu \mathrm{g} \\
\text { TLR9 agonist, } \\
3 \times 6 \text { days } \\
\text { apart }\end{array}$ & $\begin{array}{l}\mathrm{IP} ; 1 \mathrm{mg} \\
\text { ovalbumin }\end{array}$ & $\begin{array}{l}\text { Limited effect on anaphylaxis } \\
\text { score and temperature loss } \\
\text { Possible protection from } \\
\text { death }\end{array}$ & [57] \\
\hline SC & $\begin{array}{l}\text { Heat-killed Listeria } \\
\text { monocytogenes } \\
\text { (HKLM) + IgE-binding } \\
\text { modified } \\
\text { recombinant Ara h 1- } \\
3\end{array}$ & $\begin{array}{l}\text { Whole } \\
\text { roasted } \\
\text { peanut }\end{array}$ & $\begin{array}{l}\text { Mouse; } \\
\text { C3H/HeJ }\end{array}$ & $\begin{array}{l}\mathrm{IG} ; 10 \mathrm{mg} \text { whole } \\
\text { roasted peanut }+20 \\
\mu \mathrm{g} C \mathrm{CT}+1 \text {, weekly, } \\
\text { week } 1-6 \text { and } 8\end{array}$ & $\begin{array}{l}90 \text { ug } \\
\text { modified } \\
\text { recombinant } \\
\text { Ara h } 1-3 \text { with } \\
10^{8} \text { HKLM } \\
\text { weekly, } 3 \text { wks, } \\
\text { or without } \\
\text { HKLM } 3 x \\
\text { weekly, } 4 \text { wks }\end{array}$ & $\begin{array}{l}\mathrm{IG} ; 25 \mathrm{mg} \\
\text { whole } \\
\text { roasted } \\
\text { peanut } 2 \mathrm{x} \text {, } \\
30 \text { - } 40 \mathrm{~min} \\
\text { interval }\end{array}$ & $\begin{array}{l}\text { Suppression plasma } \\
\text { histamine levels, but limited } \\
\text { effect on of anaphylaxis } \\
\text { scores and temperature loss } \\
\text { Limited effect on respiratory } \\
\text { distress measured as } \\
\text { unrestrained Peak Expiratory } \\
\text { Flow } \\
\text { Decreased allergen-specific } \\
\text { IgE and increased IgG2a in } \\
\text { serum } \\
\text { Decreased allergen-specific } \\
\text { IL-4, IL-5 and IL-13, and } \\
\text { increased IFN- }- \text { production } \\
\text { by splenocytes }\end{array}$ & {$[58]$} \\
\hline
\end{tabular}

This article is protected by copyright. All rights reserved. 


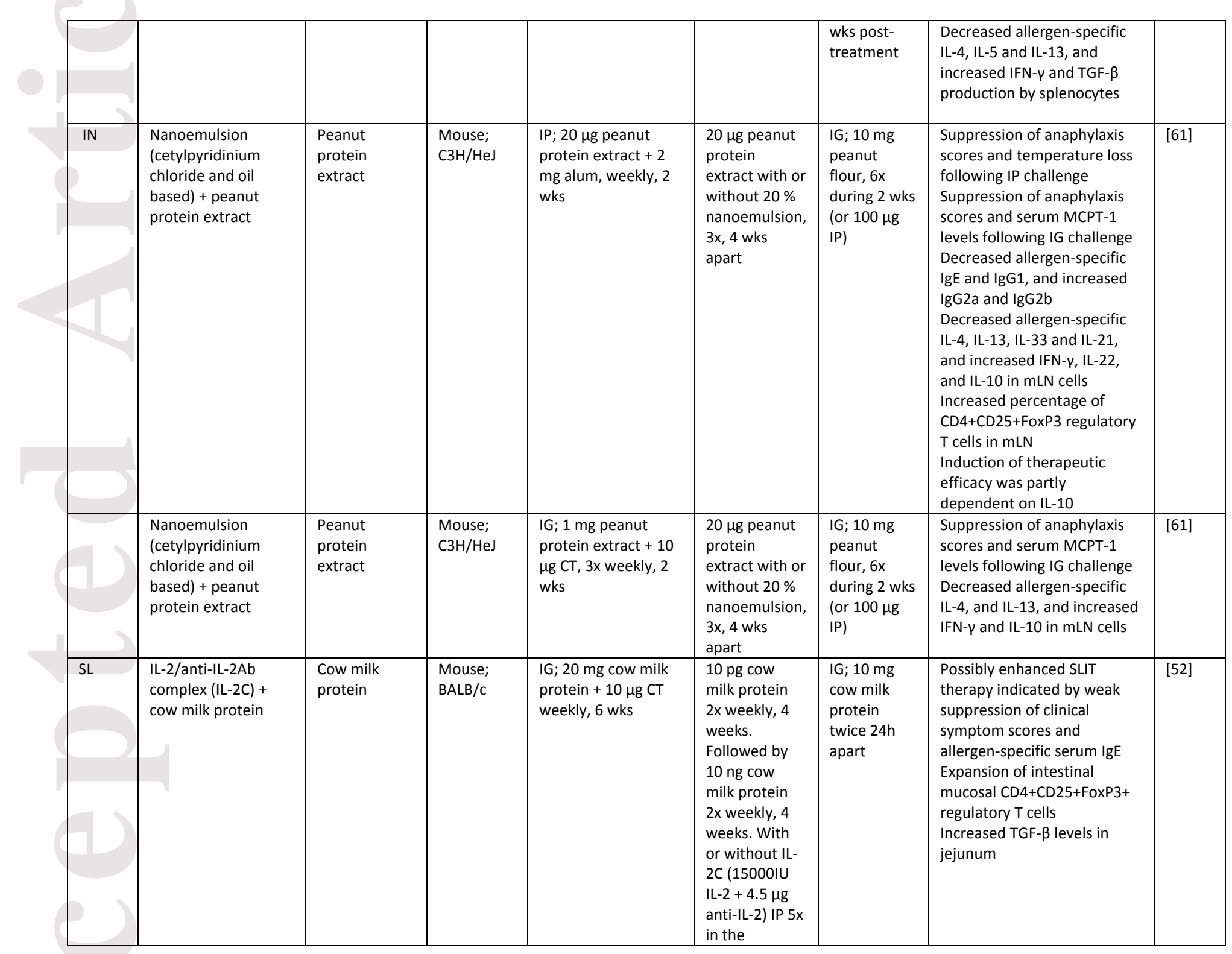

This article is protected by copyright. All rights reserved. 


\begin{tabular}{|c|c|c|c|c|c|c|c|c|}
\hline & & & & & $\begin{array}{l}\text { treatment } \\
\text { period }\end{array}$ & & & \\
\hline IV & $\begin{array}{l}\text { Peanut protein } \\
\text { extract fixed to } \\
\text { splenic leukocytes }\end{array}$ & $\begin{array}{l}\text { Peanut } \\
\text { protein } \\
\text { extract }\end{array}$ & $\begin{array}{l}\text { Mouse; } \\
\mathrm{C} 3 \mathrm{H} / \mathrm{HeJ}\end{array}$ & $\begin{array}{l}\text { IG; } 100 \mu \text { g peanut } \\
\text { protein extract }+50 \\
\mu g \text { SEB, weekly, } 8 \\
\text { wks }\end{array}$ & $\begin{array}{l}5 \times 10^{7} \\
\text { leukocytes, } \\
\text { weekly, } 2 \text { wks }\end{array}$ & $\begin{array}{l}\text { Oral; } 5 \mathrm{mg} \\
\text { peanut } \\
\text { protein } \\
\text { extract }\end{array}$ & $\begin{array}{l}\text { Weak effect on anaphylaxis } \\
\text { scores, but reversed blood } \\
\text { eosinophilia } \\
\text { Similar allergen-specific IgE } \\
\text { Decreased allergen-specific } \\
\text { IL-4 and IL-13, and similar IL- } \\
5 \text { production by splenocytes }\end{array}$ & [62] \\
\hline \multicolumn{9}{|c|}{ Cellular immunotherapy } \\
\hline IV & $\begin{array}{l}\text { CD4+CD25+ } \\
\text { regulatory T cells } \\
\text { induced by OIT, SLIT } \\
\text { or EPIT }\end{array}$ & $\begin{array}{l}\text { Peanut } \\
\text { protein } \\
\text { extract }\end{array}$ & $\begin{array}{l}\text { Mouse; } \\
\text { BALB/c }\end{array}$ & $\begin{array}{l}\text { IG; } 1 \text { mg peanut } \\
\text { protein extract }+10 \\
\mu \mathrm{g} \text { CT weekly for } 6 \\
\text { wks }\end{array}$ & $\begin{array}{l}5 \times 10^{5} \text { Treg } \\
\text { cells }\end{array}$ & $\begin{array}{l}\text { Peanut as } \\
\text { feed day } 1- \\
4, \text { peanut in } \\
\text { feed day 5- } \\
10 \text {, and } 10 \\
\text { mg peanut } \\
\text { protein } \\
\text { extract IG } \\
\text { daily the last } \\
3 \text { days } \\
\end{array}$ & $\begin{array}{l}\text { EPIT-induced CD } 4^{+} C D 25^{+} \\
\text {Tregs suppressed of } \\
\text { esophageal eosinophilia } \\
\text { Suppressed allergen-specific } \\
\text { IL-5, IL-13, IFN- } \gamma \text { and IL-10 } \\
\text { production by splenocytes }\end{array}$ & $\overline{[16]}$ \\
\hline IP & $\begin{array}{l}\text { Ovalbumin-pulsed } \\
\text { retinoic acid- } \\
\text { differentiated } \\
\text { dendritic cells (RA- } \\
\text { DCs) generated in } \\
\text { vitro }\end{array}$ & $\begin{array}{l}\text { Ovalbumin } \\
\text { (Egg) }\end{array}$ & $\begin{array}{l}\text { Mouse; } \\
\text { BALB/c }\end{array}$ & $\begin{array}{l}\text { IP; } 2 \mu \text { g ovalbumin }+ \\
2 \text { mg alum }\end{array}$ & $10^{6}$ RA-DCs & $\begin{array}{l}\mathrm{IG} ; 2 \mathrm{mg} \\
\text { ovalbumin }\end{array}$ & $\begin{array}{l}\text { Suppression of anaphylaxis } \\
\text { score, diarrhea incidence, } \\
\text { and serum mMCP-1 } \\
\text { Decreased serum allergen- } \\
\text { specific IgE and IgG1 } \\
\text { Decreased IL-4, IL-5, IL-9 and } \\
\text { IL-13 in peritoneal fluid } \\
\text { Therapeutic effect } \\
\text { dependent on IL-27 } \\
\text { production by RA-DCs }\end{array}$ & [64] \\
\hline IP & $\begin{array}{l}\text { Peanut protein- } \\
\text { pulsed retinoic acid- } \\
\text { differentiated } \\
\text { dendritic cells (RA- } \\
\text { DCs) generated in } \\
\text { vitro }\end{array}$ & $\begin{array}{l}\text { Peanut } \\
\text { protein } \\
\text { extract }\end{array}$ & $\begin{array}{l}\text { Mouse; } \\
\text { BALB/c }\end{array}$ & $\begin{array}{l}\text { IP; } 20 \mu g \text { peanut } \\
\text { protein extract }+1 \\
\text { mg alum }\end{array}$ & $10^{6}$ RA-DCs & $\begin{array}{l}\text { IG; } 50 \mathrm{mg} \\
\text { peanut } \\
\text { butter }\end{array}$ & $\begin{array}{l}\text { Suppression of anaphylaxis } \\
\text { score, diarrhea incidence, } \\
\text { and serum mMCP-1 } \\
\text { Decreased serum allergen- } \\
\text { specific IgE and IgG1 } \\
\text { Similar IL-4, IL-5, IL-9 and IL- } \\
\text { 13, and increased IL-10 in } \\
\text { peritoneal fluid }\end{array}$ & [64] \\
\hline
\end{tabular}

CMP, Cow's milk protein; CT, Cholera toxin; dNL, Draining Iymph node; EP, Epicutaneous; EPIT, Epicutaneous Immunotherapy; HK, Heat-killed; ID, Intradermal; IN, Intranasal; IG, Intragastric; IP, Intraperitoneal; IPIT, Intraperitoneal Immunotherapy; IT, Immunotherapy; IV, Intravenous; mLN, Mesenteric lymph node; PR, Per rectum; SC, Subcutaneous; SCIT, Subcutaneous immunotherapy; SL, Sublingual; SLIT, Sublingual IT; Treg, Regulatory T cell.

This article is protected by copyright. All rights reserved. 


\section{Figure legends}

Figure 1 - Overview of allergen-specific immunotherapy models in food allergy. Flowcharts show models in relation to a particular food allergy (egg, cow's milk, peanut, tree nut, and shrimp) with the specific allergen, mode of sensitization, and therapy used. The thickness of lines shows the number of models reported using the specific approach (1-8). Immunotherapeutic approaches include oral (OIT), intraperitoneal (IPIT), subcutaneous (SCIT), epicutaneous (EPIT), or sublingual (SLIT) administration of allergen, allergen in combination with immunomodulatory adjuvant (adjuvant IT) or immune cells (cellular IT), and preparations of hydrolyzed allergen or allergenderived T cell epitopes. Unless stated otherwise the reported models were conducted in mice. II4raF709 designate that the model was conducted in allergy-prone mice with gain-of-function mutation in the IL-4 receptor $\alpha$ chain.

Figure 2 - Overview of clinical and immunological outcomes assessed within allergen-specific immunotherapy models in food allergy. Outcomes has been divided into clinical (symptoms), paraclinical (histology), and immunological (serology, systemic and tissue immune responses) measures.

This article is protected by copyright. All rights reserved. 


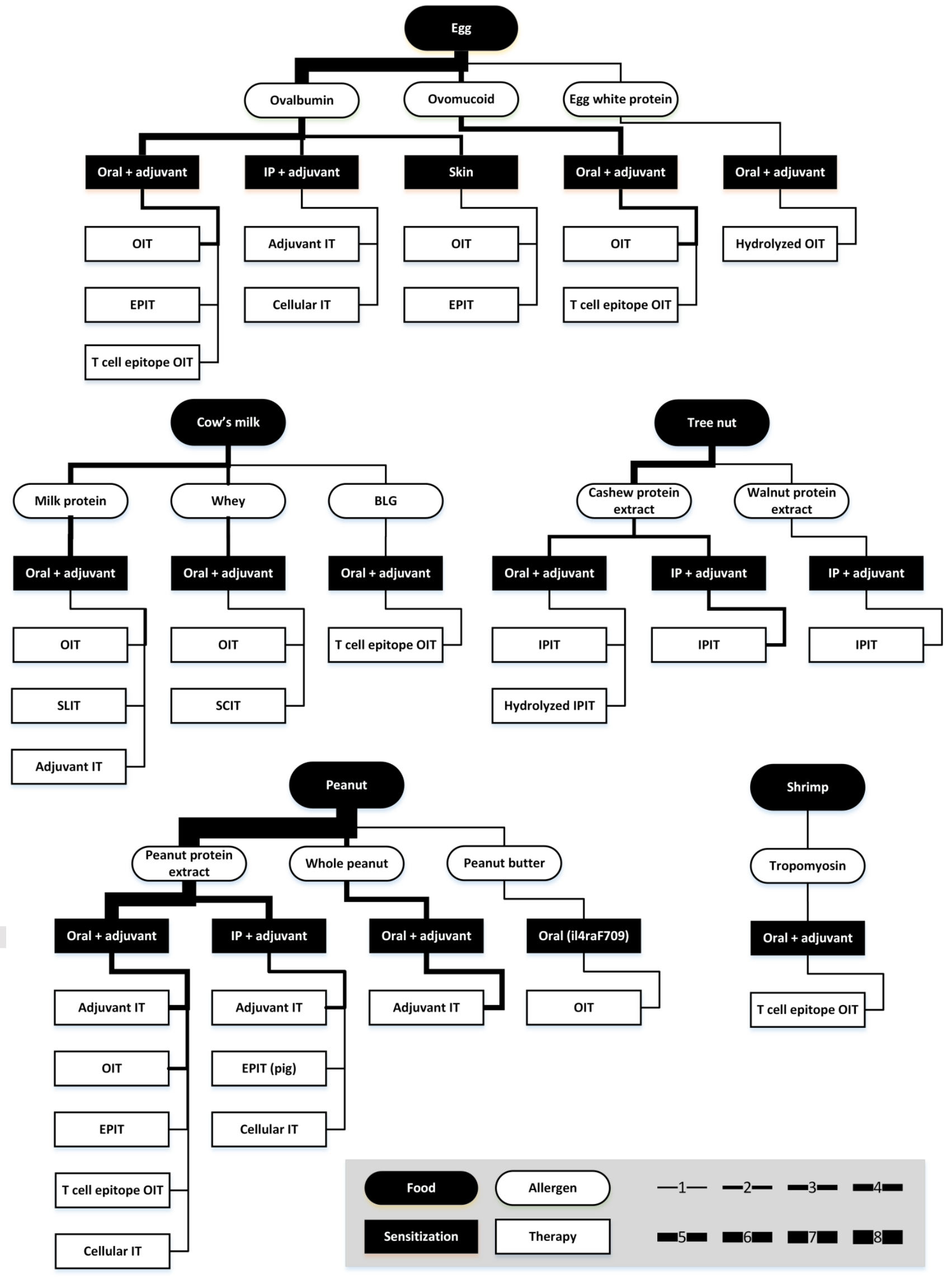

This article is protected by copyright. All rights reserved. 


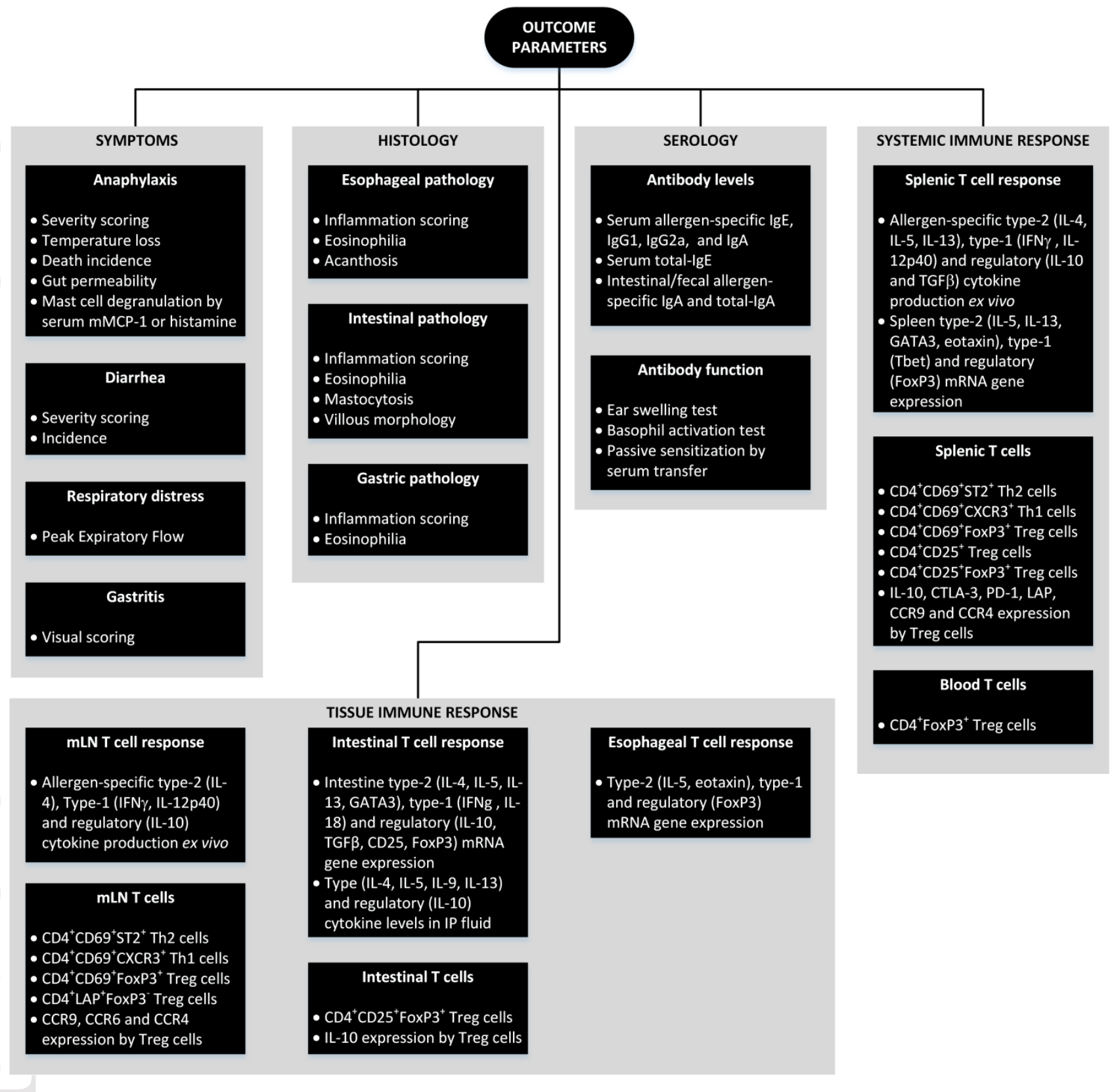

This article is protected by copyright. All rights reserved. 